\title{
Depositional Environments of the White Rim Sandstone Member of the Permian Cutler Formation, Canyonlands National Park, Utah
}

\section{U.S. GEOLOGICAL SURVEY BULLETIN 1592}





\section{Depositional Environments of the White Rim Sandstone Member of the Permian Cutler Formation, Canyonlands National Park, Utah}

By Brenda A. Steele

Interpretation of depositional environments and distributions of dune, interdune, and sabkha deposits in the White Rim Sandstone Member, concentrating on the area between the Green and Colorado Rivers. 


\section{DEPARTMENT OF THE INTERIOR DONALD PAUL HODEL, Secretary \\ U.S. GEOLOGICAL SURVEY \\ Dallas L. Peck, Director}

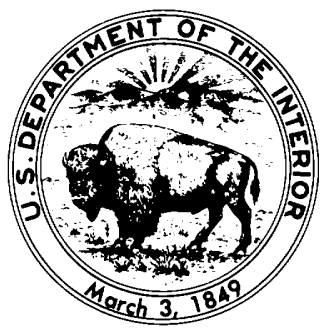

For sale by the

Books and Open-File Reports Section

U.S. Geological Survey

Federal Center

Box 25425

Denver, CO 80225

Library of Congress Cataloging in Publication Data

Steele, Brenda A.

Depositional environments of the White Rim sandstone member of the Permian Cutler formation, Canyonlands National Park, Utah.

(U.S. Geological Survey bulletin ; 1592)

"Interpretation of depositional environments and distributions of dune, interdune, and sabkha deposits

in the White Rim sandstone member, concentrating on the area between the Green and Colorado Rivers."

Bibliography: $p$.

Supt. of Docs no.: I 19.3:1592

1. Sandstone-Utah-Canyonlands National Park. 2. Geology, Stratigraphic-Permian. I. Title. II. Series. 


\title{
CONTENTS
}

\author{
Abstract 1 \\ Introduction $\mathbf{1}$ \\ Geologic setting $\mathbf{3}$ \\ Methods of study $\mathbf{3}$ \\ Permian Stratigraphy $\mathbf{3}$ \\ White Rim Sandstone Member 4 \\ Stratigraphic relationships $\mathbf{5}$ \\ Interpretation of depositional environments \\ Dune deposits 7 \\ Interdune deposits 9 \\ Sabkha deposits $\mathbf{1 2}$ \\ Relationship of dune and interdune deposits 13 \\ Depositional setting $\mathbf{1 3}$ \\ Economic geology 17 \\ Conclusions 17 \\ References cited $\mathbf{1 8}$
}

\section{FIGURES}

1. Index map of Canyonlands National Park and surrounding area $\mathbf{1}$

2. White Rim Sandstone Member, view of type locality $\mathbf{2}$

3. Detailed map of study area showing locations of measured sections $\mathbf{3}$

4. Generalized stratigraphic chart of Canyonlands National Park 4

5. Generalized east-west stratigraphic section 4

6. Isopach map of White Rim Sandstone Member 4

7. White Rim Sandstone Member eastern pinchout $\mathbf{5}$

8. Tabular planar crossbed sets with tangential bases, dune deposit $\mathbf{6}$

9. Sand flow toes, dune deposit 7

10. Inversely graded ripple strata, dune deposit $\mathbf{8}$

11. Equal-area rose diagram of crossbedding dip direction measurements $\mathbf{8}$

12. High-index ripples, dune deposit $\mathbf{8}$

13. Ripple strata forming pin-striped bedding, dune deposit $\mathbf{8}$

14. Bimodal erosional lag, dry deflationary interdune 9

15. Textural inversion, dry deflationary interdune $\mathbf{1 0}$

16. Wavy, horizontally laminated bedding, depositional interdune $\mathbf{1 0}$

17. Plan view of adhesion ripples, depositional interdune $\mathbf{1 0}$

18. Plan view of desiccation polygons, depositional interdune $\mathbf{1 1}$

19. Bioturbation, bedding plane surface, depositional interdune $\mathbf{1 2}$

20. Dolomite rhombohedrons, depositional interdune $\mathbf{1 3}$

21. Schematic fence diagram White Rim Sandstone Member dune, interdune and sabkha deposits $\mathbf{1 4}$

22. Interbedded dune and depositional interdune deposits $\mathbf{1 5}$

23. Schematic diagram of White Rim Sandstone Member depositional setting $\mathbf{1 5}$

24. Paleogeographic map of Canyonlands National Park and surrounding area 16

25. Glauconite pellet, dune deposit $\mathbf{1 7}$ 



\title{
Depositional Environments of the White Rim Sandstone Member of the Permian Cutler Formation, Canyonlands National Park, Utah
}

\author{
By Brenda A. Steele
}

\section{Abstract}

The White Rim Sandstone Member of the Permian Cutler Formation in Canyonlands National Park, southeastern Utah, was deposited in a coastal eolian environment. The White Rim consists of three types of eolian deposits: dune, interdune, and sabkha. Characteristics of the dune deposits are large-to medium-scale, unidirectional, tabular planar crossbed sets; high-index ripples oriented parallel to the dip direction of the foresets; inverse graded laminations formed by ripple migration; sand-flow toes; and raindrop impressions. Interdune deposits are of two types, erosional and depositional, formed under varying degrees of wetness. Erosional interdune deposits are characterized by thin, coarse sand to granule size, bimodal lags at the base of crossbed sets. Depositional interdune deposits are characterized by discontinuous, wavy horizontal laminations, color banding, adhesion ripples, relict salt-ridge structures, and bioturbation. Generally, both types of interdune deposits are thin and lenticular. In the eastern part of the study area the entire lower half of the White Rim is flatbedded sandstone that has most of the characteristics of depositional interdune deposits. A detrital-dominant, inland sabkha, which formed downwind of the main White Rim dune field, may be represented by this flatbedded sandstone. Location of the sabkha was topographically controlled by early movement of the Monument upwarp and grew as the result of a stable and slowly rising water table.

The Lower Permian White Rim Sandstone Member was deposited during a period of marine transgression when the area of Canyonlands National Park was exposed to alternating marine and nonmarine conditions. Permian paleogeography and stratigraphic relationships, sand body geometry, dune form, and petrologic features such as glauconite pellets, a crinoid fragment, and heavy mineral concentrations all indicate the White Rim Sandstone Member was deposited in a coastal setting.

\section{INTRODUCTION}

Canyonlands National Park in southeastern Utah (fig. 1) has some of the most spectacular and colorful

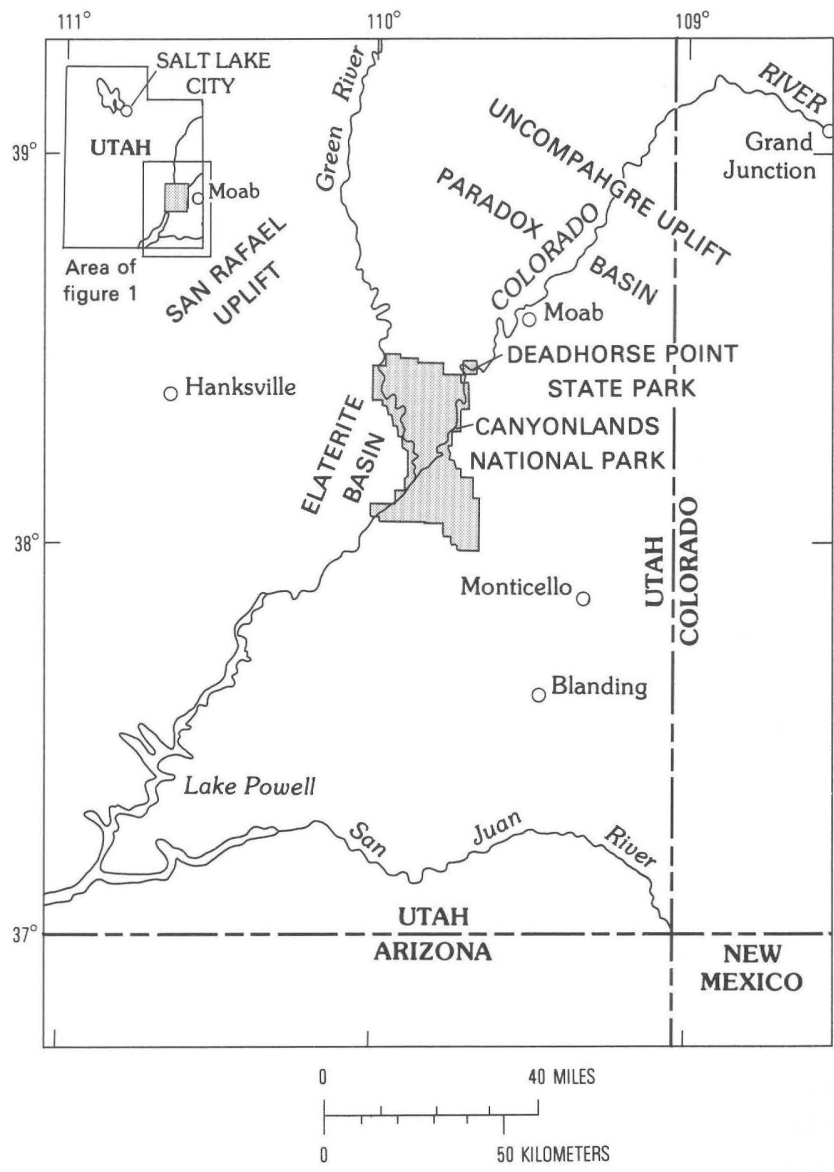

Figure 1. Index map of Canyonlands National Park and surrounding area. 


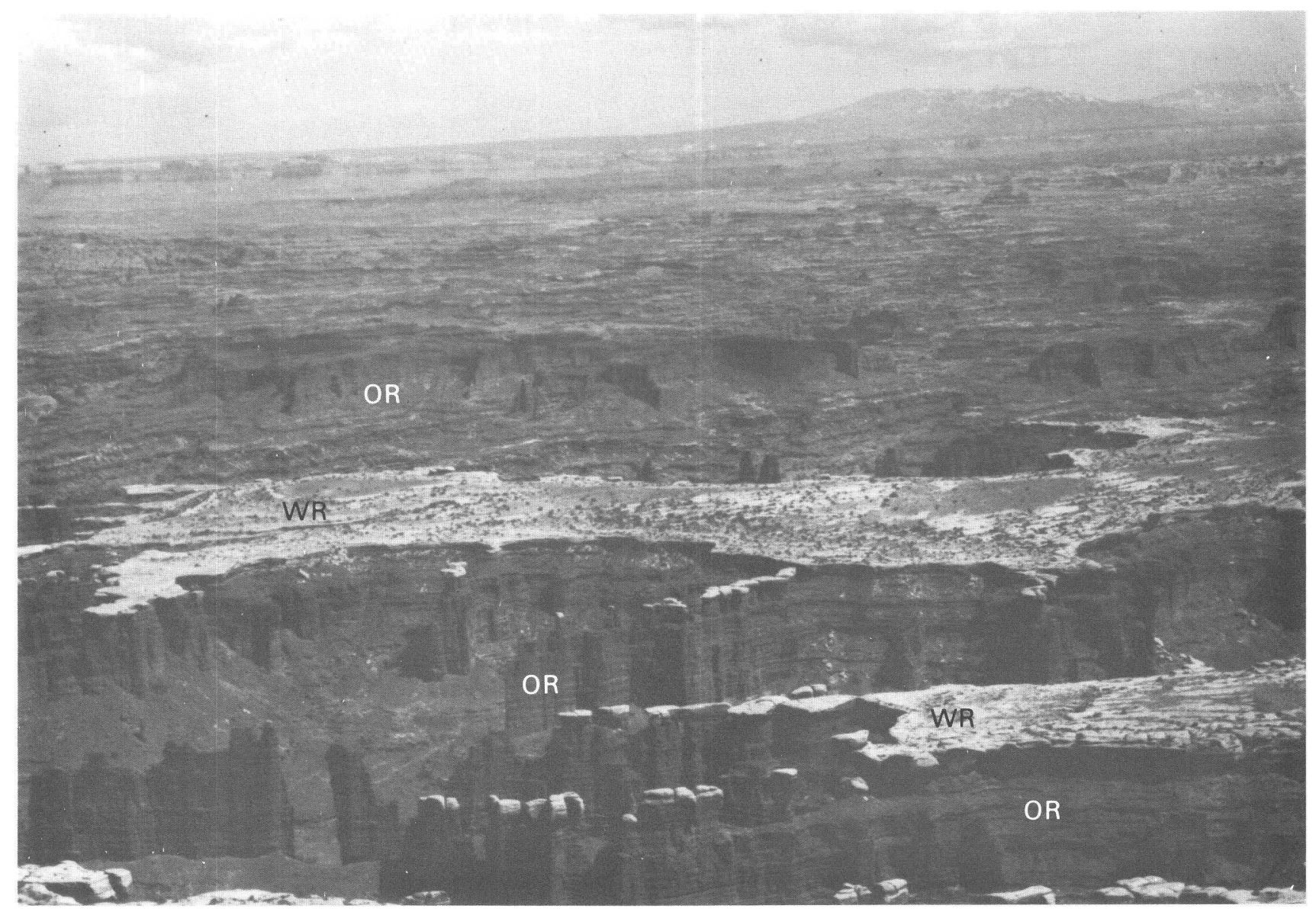

Figure 2. White Rim Sandstone (WR) and underlying Organ Rock (OR) Members of Permian Cutler Formation, type locality, looking south toward confluence of the Green and Colorado Rivers. Thickness of White Rim is approximately $14 \mathrm{~m}$.

canyon scenery in the country. One of the most recognizable units exposed along the canyon wall in the park is the White Rim Sandstone Member of the Permian Cutler Formation, which forms a conspicuous white ledge surrounded by dominantly reddish-brown sandstone and shale (fig. 2). The abundant, large-to medium-scale, unidirectional, tabular planar crossbedding in the White Rim prompted early workers in the region to conclude that, for the most part, it represents ancient dunes deposited in an eolian environment (Baker and Reeside, 1929; McKnight, 1940; Baker, 1946; Kunkel, 1958; Heylmun, 1958; and Hallgarth, 1967a).

The first detailed study of the White Rim Sandstone Member was done by Baars and Seager (1970) and was concentrated in the Elaterite Basin area (fig. 1). They concluded the White Rim is almost entirely shallow marine and only the easternmost part, near the base of Shafer Trail (fig. 3), is eolian. This interpretation was based on a detailed analysis of sedimentary structures and on the presence of a problematic (alga?) fossil found in Elaterite
Basin. The large-scale, unidirectional cross stratification in the White Rim was interpreted to represent numerous, elongate, offshore bar deposits formed by longshore currents moving from the northwest. Also, according to Baars and Seager (1970), these bar deposits invariably overlie horizontally bedded material in the area between the Green and Colorado Rivers. They interpreted the horizontal bedding to represent a regressive sequence, and the offshore bars a transgressive sequence.

In order to resolve this difference in interpretation, a detailed study of the White Rim was conducted in the area between the Green and Colorado Rivers in Canyonlands National Park (fig. 3). Stratigraphic relationships, sedimentary structures, and petrographic characteristics of the White Rim were examined. Results from this study indicate the White Rim was deposited in an eolian system and contains dune, interdune, and sabkha deposits. Also, the White Rim has a close marine association and represents a coastal dune field (Steele-Mallory, 1981a). 


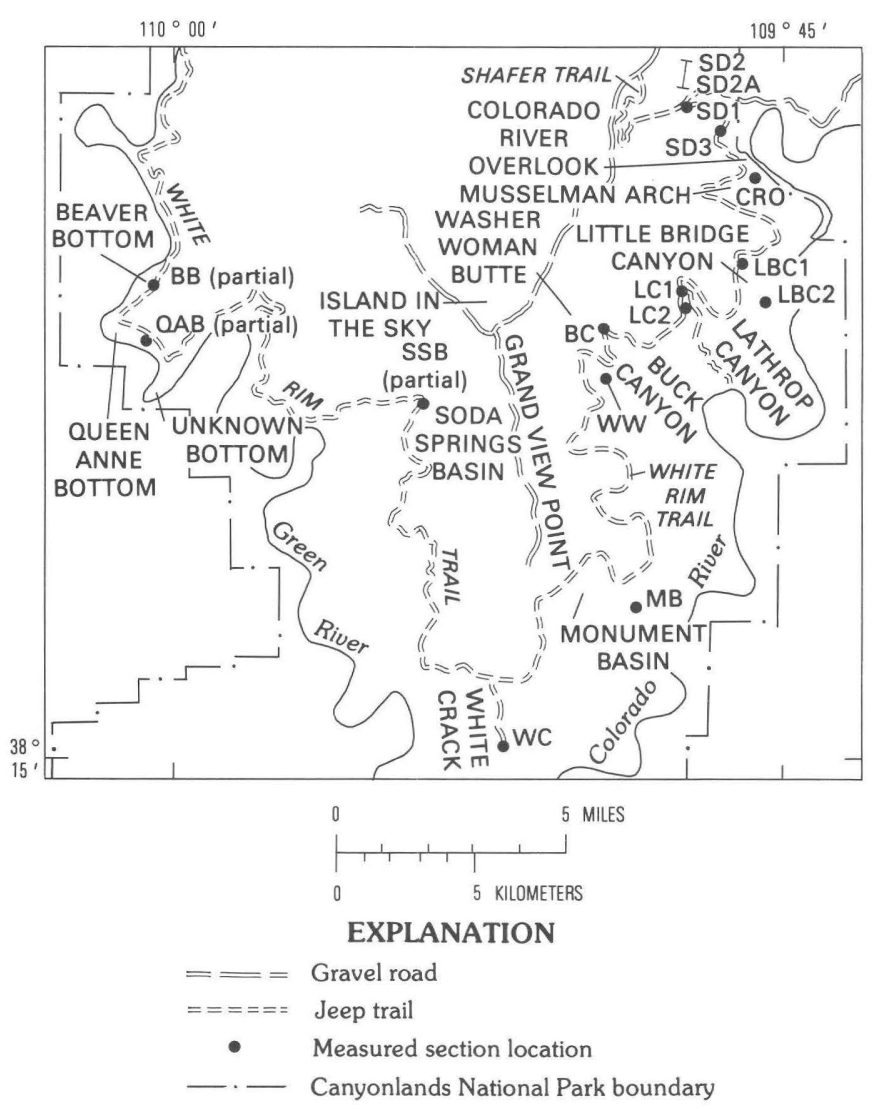

Figure 3. Detailed map of study area showing locations of measured sections.

\section{Geologic Setting}

Canyonlands National Park is located in the northcentral portion of the Colorado Plateau and is part of the Canyonlands section of the Plateau (Fenneman, 1928). The Canyonlands section is essentially a large plateau surface that has been epeirogenically upwarped and broadly folded (Hunt, 1956). Entrenchment of the Green and Colorado Rivers and their tributaries on this surface in the last 5 million years (Trumble, 1980) has formed a series of deep canyons. The present study was done in the Island in the Sky district of the park, which includes the 60-kmwide erosional basin of the Green and Colorado Rivers (fig. 3).

Almost continuous sedimentary deposition in the Canyonlands region throughout much of the Paleozoic, Mesozoic and Cenozoic Eras resulted in a thick accumulation of sediments, which exhibit diverse compositions. Late Tertiary to Holocene erosion has completely removed the entire Cenozoic and part of the Mesozoic record. Presently, relatively undeformed rocks of Pennsylvanian to Jurassic age are exposed in the park (fig. 4). Baars and Molenaar (1971), Lohman (1974), and Fassett and Wengerd (1975) have discussed the geologic history of Canyonlands.

\section{Methods of study}

The White Rim Sandstone Member is excellently exposed in canyon walls of the Green and Colorado Rivers (fig. 2). The White Rim trail, a primitive four-wheel drive road (fig. 3), gives limited access to outcrops. Twelve complete and three partial stratigraphic sections were measured, described, and sampled. Stratigraphic sections were spaced in order to attain maximum coverage of the White Rim throughout the study area (fig. 3), but working access to full sections of the White Rim is limited because it forms steep, unscalable cliffs. Complete descriptions of the measured sections are given in SteeleMallory (1981b and 1982).

In the course of measuring and describing stratigraphic sections, emphasis was placed on the examination and description of primary sedimentary structures, including their size, orientation, and morphology. Mean crossbed dip directions were calculated for each measured section by the vector summation method first used by Reiche (1938). Equal-area rose diagrams of all crossbed dip directions were made. These were used to classify dune types and to help reconstruct the depositional history of the White Rim. Local and regional geologic relationships of the White Rim to adjacent stratigraphic sequences also were examined to help reconstruct the White Rim's depositional history.

At each measured section, the White Rim and the overlying and underlying units were sampled for thin sections. A detailed petrographic examination was made of 107 thin sections to identify textures, mineralogy, and diagenetic features. Complete descriptions of the thin sections are given in Steele-Mallory (1981b and 1982).

\section{PERMIAN STRATIGRAPHY}

During Permian-Pennsylvanian time, southeastern Utah underwent a period of orogenic activity. Major structural features formed were the northwest-southeast trending Uncompahgre uplift and the adjacent, parallel-trending Paradox basin (fig. 1). Both features greatly influenced Permian depositional patterns in the region. Figure 5 is a generalized stratigraphic section for Canyonlands and the surrounding area. Throughout much of the Early Permian, the Uncompahgre uplift (fig. 1) contributed large amounts of detrital material to the area, resulting in a 900- to 2,400 m-thick accumulation of continental clastic material adjacent to the uplift, the undifferentiated Cutler Formation (Williams, 1964; Campbell, 1980). At the same time, marine conditions prevailed to the west, in south-central Utah and northern Arizona (Hallgarth, 1967a). Sediments deposited in both marine and continental environments interfinger in Canyonlands (Baars and Molenaar, 1971). The Rico Formation (Elephant Canyon Formation of Baars, 1962) and the Organ Rock, Cedar 


\begin{tabular}{|c|c|c|c|}
\hline AGE & \multicolumn{2}{|c|}{ NAME } & $\begin{array}{l}\text { THICKNESS } \\
\text { (METERS) }\end{array}$ \\
\hline \multirow{4}{*}{$\begin{array}{l}\frac{u}{5} \\
\frac{0}{4} \\
\frac{\alpha}{5} \\
\stackrel{5}{5}\end{array}$} & \multirow{3}{*}{$\begin{array}{l}\text { Entrada } \\
\text { Sandstone }\end{array}$} & Moab Member & \multirow{3}{*}{$122-152$} \\
\hline & & $\begin{array}{l}\text { Slick Rock } \\
\text { Member }\end{array}$ & \\
\hline & & $\begin{array}{c}\text { Dewey Bridge } \\
\text { Member }\end{array}$ & \\
\hline & \multirow{3}{*}{$\begin{array}{l}\text { Glen } \\
\text { Canyon } \\
\text { Group }\end{array}$} & $\begin{array}{l}\text { Navajo } \\
\text { Sandstone }\end{array}$ & $99-168$ \\
\hline \multirow{6}{*}{ 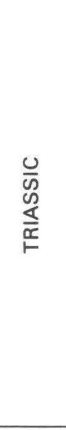 } & & $\begin{array}{l}\text { Kayenta } \\
\text { Formation }\end{array}$ & $49-91$ \\
\hline & & $\begin{array}{l}\text { Wingate } \\
\text { Sandstone }\end{array}$ & $64-104$ \\
\hline & \multirow{2}{*}{$\begin{array}{l}\text { Chinle } \\
\text { Formation }\end{array}$} & $\begin{array}{l}\text { Unnamed } \\
\text { upper member }\end{array}$ & $63-226$ \\
\hline & & $\begin{array}{c}\text { Moss Back } \\
\text { Member }\end{array}$ & $0-24$ \\
\hline & \multirow{2}{*}{$\begin{array}{l}\text { Moenkopi } \\
\text { Formation }\end{array}$} & $\begin{array}{c}\text { Unnamed } \\
\text { upper member }\end{array}$ & $76-287$ \\
\hline & & $\begin{array}{l}\text { Hoskinnini } \\
\text { Member }\end{array}$ & $0-37$ \\
\hline \multirow{4}{*}{ 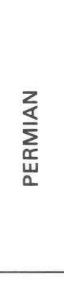 } & \multirow{3}{*}{$\begin{array}{l}\text { Cutler } \\
\text { Formation }\end{array}$} & $\begin{array}{l}\text { White Rim } \\
\text { Sandstone Member }\end{array}$ & \multirow{3}{*}{ 244-305 } \\
\hline & & $\begin{array}{l}\text { Organ Rock } \\
\text { Member }\end{array}$ & \\
\hline & & $\begin{array}{c}\text { Cedar Mesa } \\
\text { Sandstone Member }\end{array}$ & \\
\hline & \multicolumn{2}{|c|}{$\begin{array}{c}\text { Rico Formation } \\
\text { (Elephant Canyon Formation }{ }^{1} \text { ) }\end{array}$} & $76-178$ \\
\hline \multirow{2}{*}{ 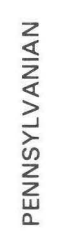 } & \multirow{2}{*}{$\begin{array}{l}\text { Hermosa } \\
\text { Group }{ }^{1}\end{array}$} & $\begin{array}{l}\text { Honaker Trail } \\
\text { Formation }{ }^{1}\end{array}$ & $274-549$ \\
\hline & & $\begin{array}{l}\text { Paradox } \\
\text { Formation }{ }^{1}\end{array}$ & $?$ \\
\hline
\end{tabular}

${ }^{1}$ of Baars, 1962

Figure 4. Generalized stratigraphic chart of Canyonlands national Park (modified from Lohman, 1974).

Mesa Sandstone, and White Rim Sandstone Members of the Cutler Formation were all deposited in this complex depositional setting.

\section{White Rim Sandstone Member}

Baker and Reeside (1929) named the White Rim Sandstone Member for exposures of a light-colored, cliffforming sandstone, forming a prominent bench between the Green and Colorado Rivers. It is the upper of two light-colored sandstone units of the Permian Cutler Formation in Canyonlands. The determination of the age of the White Rim depends on regional correlations because direct dating is not possible. The White Rim overlies the Wolfcampian Rico Formation, (also called the Elephant Canyon Formation of Baars, 1962), and was most likely deposited during late Leonardian to early Guadalupian time (Baars, 1962; Hallgarth, 1967a).

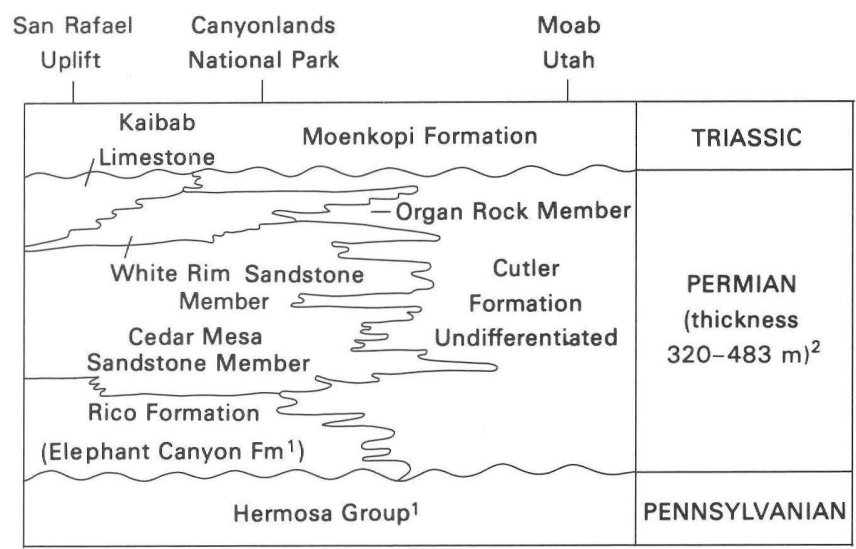

1 of Baars, 1962

2Lohman, 1974

Figure 5. Generalized east-west stratigraphic section, Canyonlands National Park and surrounding area (modified from Baars and Seager, 1970).

Regionally, the White Rim forms an elongate, northeast-southwest-trending sandstone body (fig. 6) that abruptly pinches out eastward into the Organ Rock Member (fig. 7) and an overlying unnamed unit that may be Permian or Triassic in age, and dips gradually to the

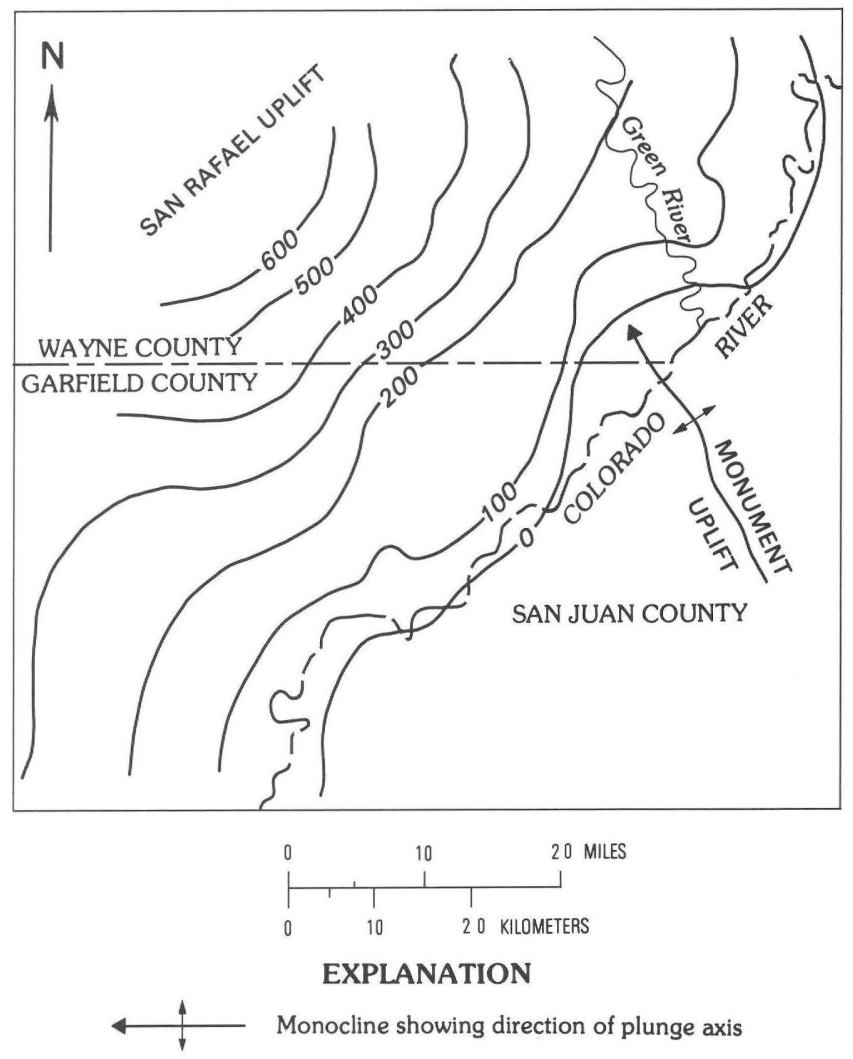

Figure 6. Isopach map of White Rim Sandstone Member (modified from Baars and Seager, 1970). 
northwest where it thickens to an estimated $220 \mathrm{~m}$ (Baars and Seager, 1970). Part of the eastern pinchout closely parallels the western flank and northern plunge of the Monument upwarp, indicating this structure was active during Permian time (Baars, 1979).

\section{Stratigraphic Relationships}

The study area is close to the eastern pinchout of the White Rim. Throughout most of this area the White Rim conformably overlies the reddish-brown sandstones and silty shales of the Organ Rock Member. Depositional environments of the Organ Rock are interpreted as fluvial channel and related flood plain (Baars and Molenaar, 1971, Campbell, 1980). In the southern part of the study area the White Rim may conformably overlie the Cedar Mesa Sandstone Member (Steele-Mallory, 1981b; 1982). Early workers in the region, McKnight (1940) and Baker (1946), considered the Cedar Mesa to be eolian. Baars (1962, 1979), Blakey (1979), and Mack (1979) all considered the Cedar Mesa to be largely shallow marine, but recent studies by Loope (1984) also interpreted this unit as eolian. In addition, Campbell and Stanesco (1983) and Loope (1984) recognized fluvial deposits in the Cedar Mesa.

The White Rim in the study area is overlain by a reddish-brown mottled, massively bedded, poorly sorted arkosic sandstone that may be bioturbated (Steele-Mallory, 1981b, 1982). Little has been written on this unnamed unit, and its relationship to the White Rim is not clearly understood. McKnight (1940), Kunkel (1958), and Baars and Seager (1970) considered this unit to be an unnamed sandstone in the Cutler Formation. Baker (1946) and Hallgarth (1967a) considered the unit to be part of the Triassic Moenkopi Formation and placed the PermianTriassic boundary at the top of the White Rim. This unit is not laterally persistent. Southwest of the study area, near Elaterite Basin (fig. 1), the Triassic Moenkopi contains a basal conglomerate and unconformably overlies the White Rim (Baars and Seager, 1970).

The contact between the White Rim and the underlying units is sharp, planar, and distinct, and no scouring

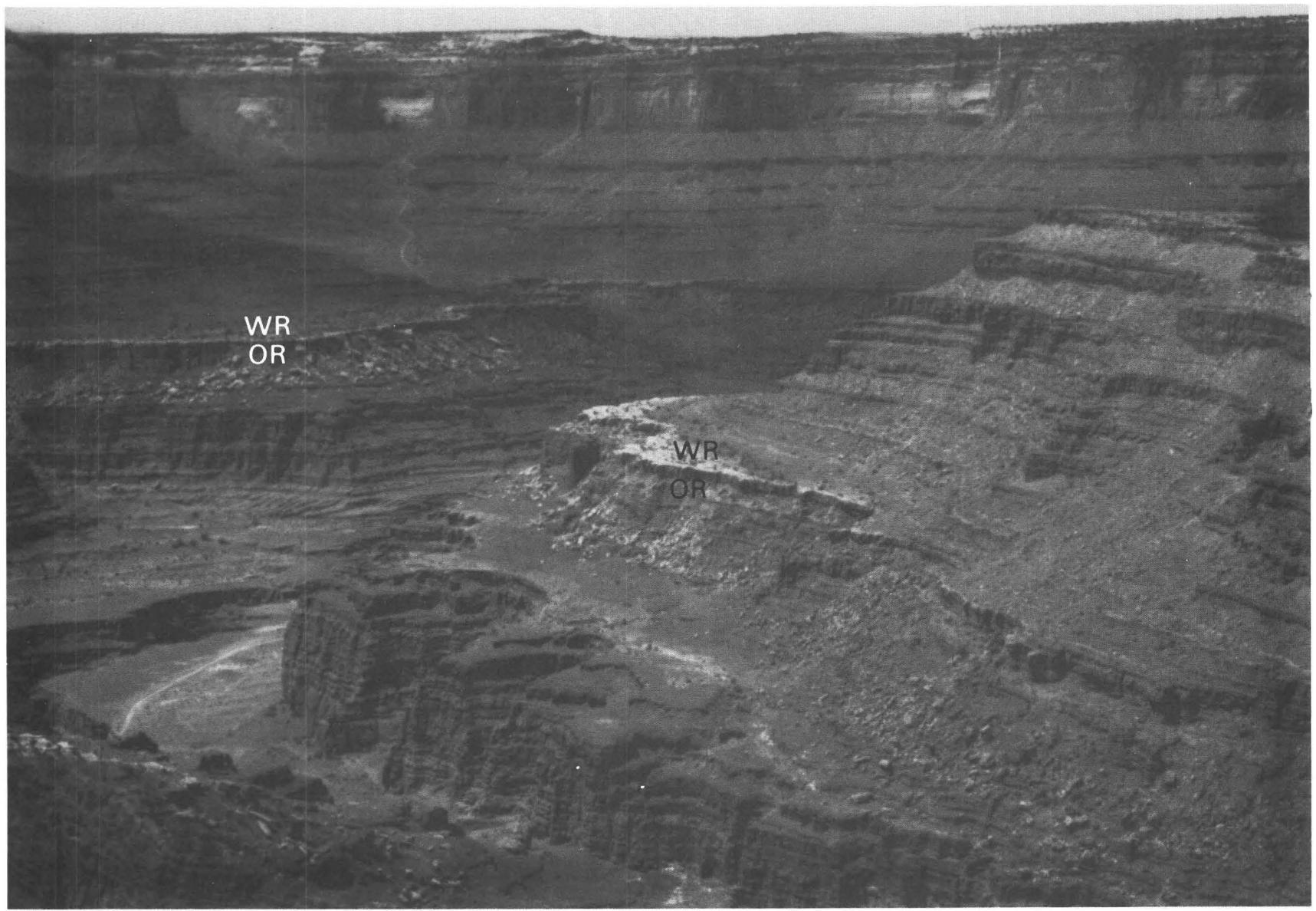

Figure 7. Eastern pinchout of White Rim Sandstone Member (WR) into Organ Rock Member (OR) and overlying unnamed unit, looking south into Canyonlands National Park from Deadhorse Point State Park. 


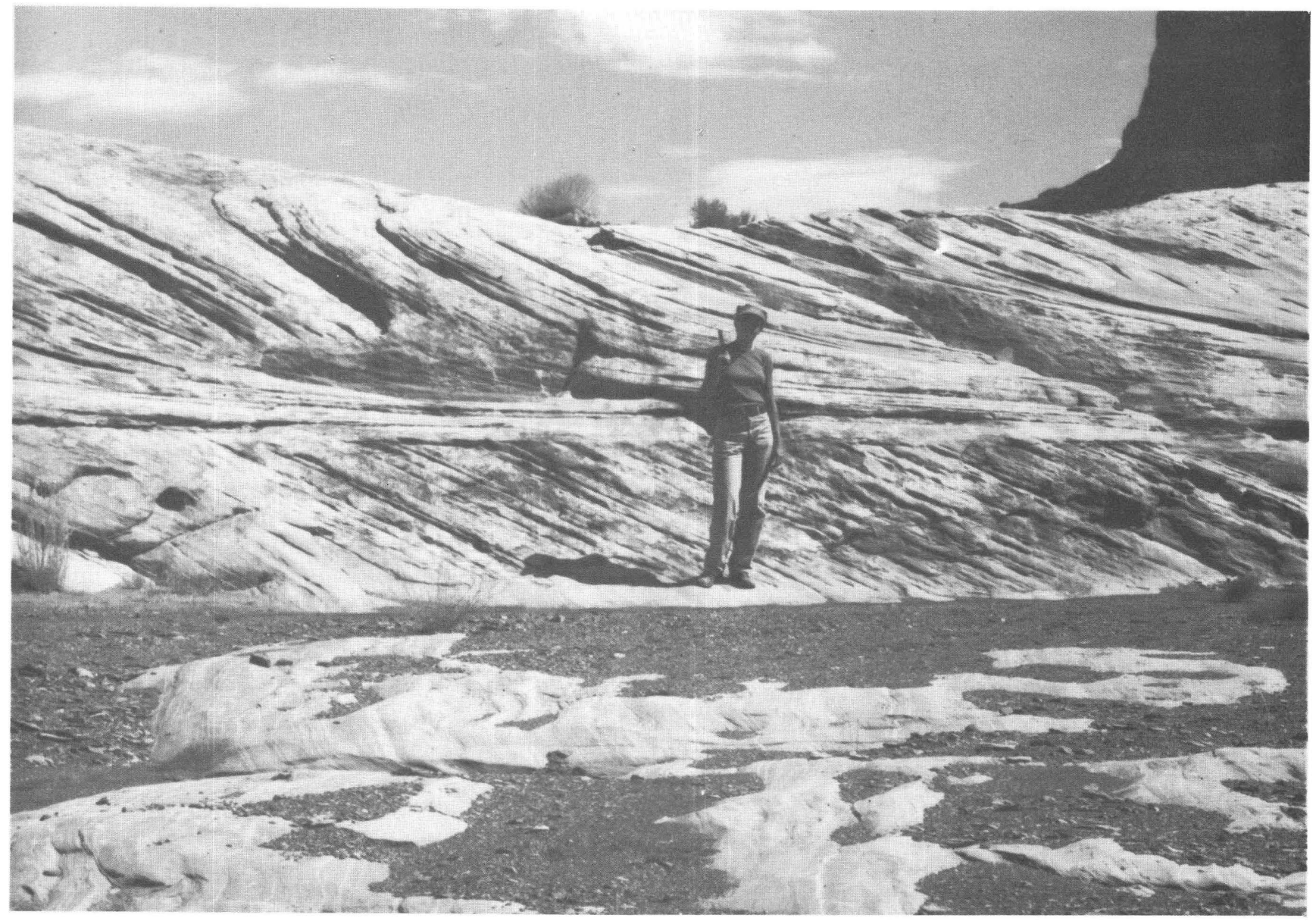

Figure 8. Tabular planar crossbed sets in dune deposit, showing concave upward laminations forming tangential bases and a nearly horizontal bounding surface between sets, top of Beaver Bottom section.

by the White Rim is evident. The top of the Organ Rock and Cedar Mesa Sandstone Members is commonly bleached and intensely altered with most feldspar grains destroyed, mica grains bleached and expanded, and abundant authigenic kaolinite (Steele-Mallory, 1981b, 1982). The upper contact of the White Rim is also typically sharp and distinct but irregular, undulating a meter or more. This irregularity most likely represents a paleotopographic surface and may be related to the eolian nature of the White Rim.

The most widely accepted lateral equivalents of the White Rim are the upper part of the Leonardian Toroweap Formation and the Leonardian gamma member of the Kaibab Limestone found in south-central Utah and northern Arizona (Kunkel, 1958; Heylmun, 1958; Hallgarth, 1967a; Baars and Seager, 1970; Irwin, 1971). The Toroweap consists of sandstone, carbonate, and evaporite deposited in restricted marine and related coastal eolian and sabkha environments (Hallgarth, 1967a; Rawson and Turner-Peterson, 1979). The gamma member of the Kaibab consists of carbonate, evaporite, and siltstone de- posited in restricted marine and related coastal sabkha environments (McKee, 1954; Cheevers and Rawson, 1979).

\section{INTERPRETATION OF DEPOSITIONAL ENVIRONMENTS}

The White Rim Sandstone Member in Canyonlands National Park was deposited in an eolian system. Unlike many other depositional environments, no single facies model exists for eolian systems, resulting in no preferred vertical sequences nor any consistent lateral changes (Walker, 1979). Ancient eolian deposits may best be recognized by the presence of features that are characteristic of, or at least compatible with, a modern eolian environment (McKee and Bigarella, 1979a). Glennie (1970), Bigarella (1972), McKee and Bigarella (1979a, b), Hunter (1977), Kocurek and Dott (1981), and Ahlbrandt and Fryberger (1982) gave good general discussions of different features of eolian deposits. Some of the more important characteristic features are: 


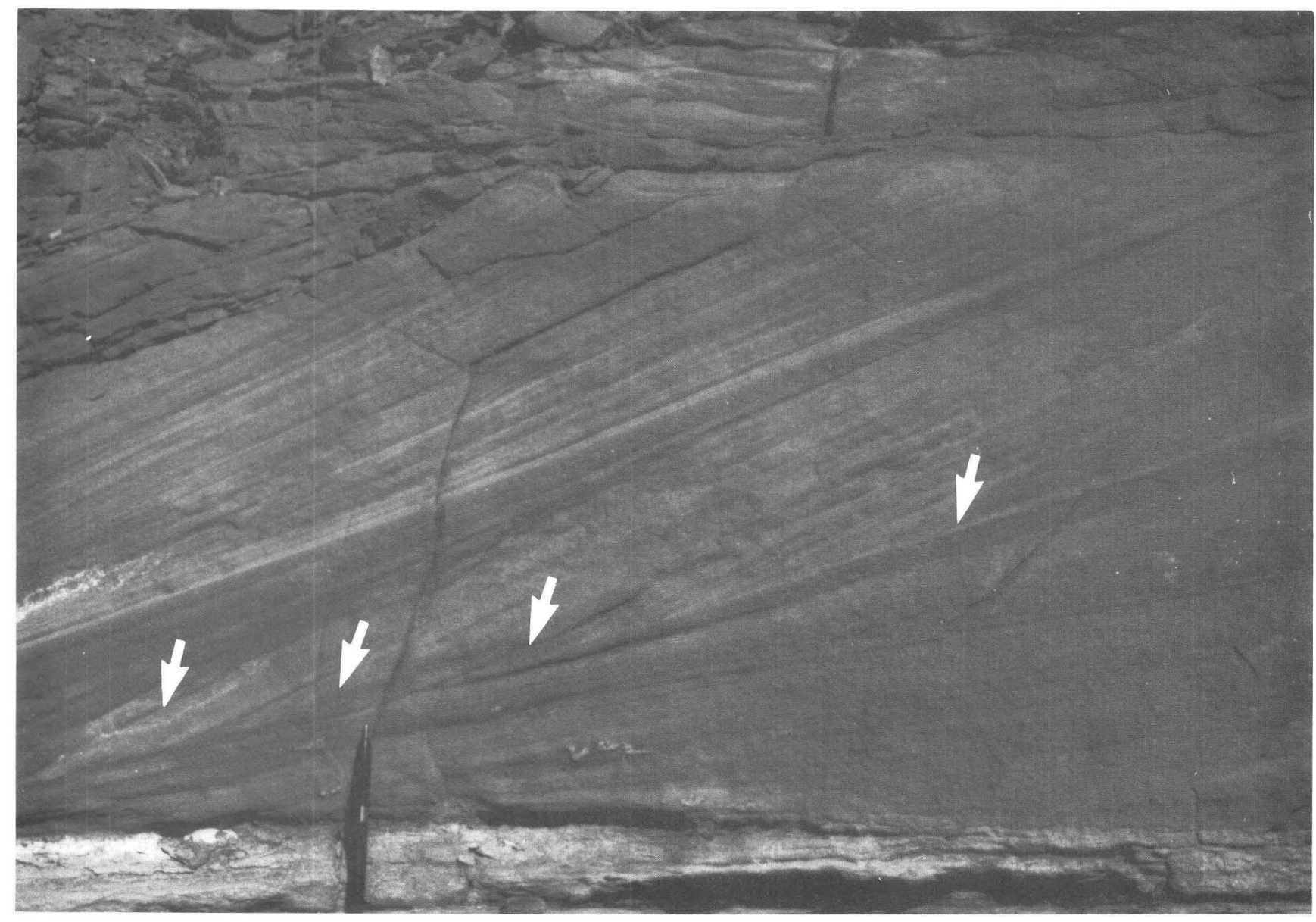

Figure 9. Tongue-shaped sand flow toes (arrows) near base of crossbed set, dune deposit, base of Shafer Trail.

1. Sets of medium- to large-scale tabular planar or wedge planar crossbeds that dip down wind.

2. Bounding surfaces between crossbed sets that are either horizontal or inclined at low angles.

3. High-index ripples, R.I. $>15$, oriented parallel or subparallel to the dip direction of the foresets.

4. Inverse graded laminations within crossbed sets.

5. Sand flow toes.

6. Coarse-grained lags between crossbed sets that are often bimodal.

7. Signs of exposure to subaerial conditions such as raindrop impressions, root structures, or animal tracks and trails.

Detailed examination of the White Rim reveals the presence of many of these features. Dune, interdune, and sabkha deposits are recognized. Each of these deposits has distinctive sedimentary structures and petrologic features.

\section{Dune Deposits}

The most prominent feature of the dune deposits is the conspicuoustabular planar crossbedding. Thickness- es range from less than $0.5 \mathrm{~m}$ to $6 \mathrm{~m}$, averaging 1.5 $\mathrm{m}$. Laminations near the base of each set are commonly concave upward, forming long, sweeping tangential bases that become nearly horizontal (fig. 8). Small-scale stratification features observed within the dune sets are tongueshaped sand flow toes near the base of crossbed sets, related to avalanching of noncohesive sand on the dune slip faces (fig. 9); normally graded strata related to grainfall processes; and inversely graded strata related to ripple migration (fig. 10). All of these features are consistent with eolian depositional processes (Hunter, 1977; Ahlbrandt and Fryberger, 1982).

Crossbedding dip directions are strongly unidirectional (fig. 11), having a vector mean dip direction of S. 47 E., and an average dip angle of $22^{\circ}$. This strongly unidirectional, northwest to southeast trend of the crossbeds suggests the dune form was most likely either barchanoid or transverse ridges (McKee, 1979a). These dune types are commonly oriented at approximately right angles to the dominant effective wind direction and are the result of moderate winds and fairly abundant sand supply (McKee, 1979b). 


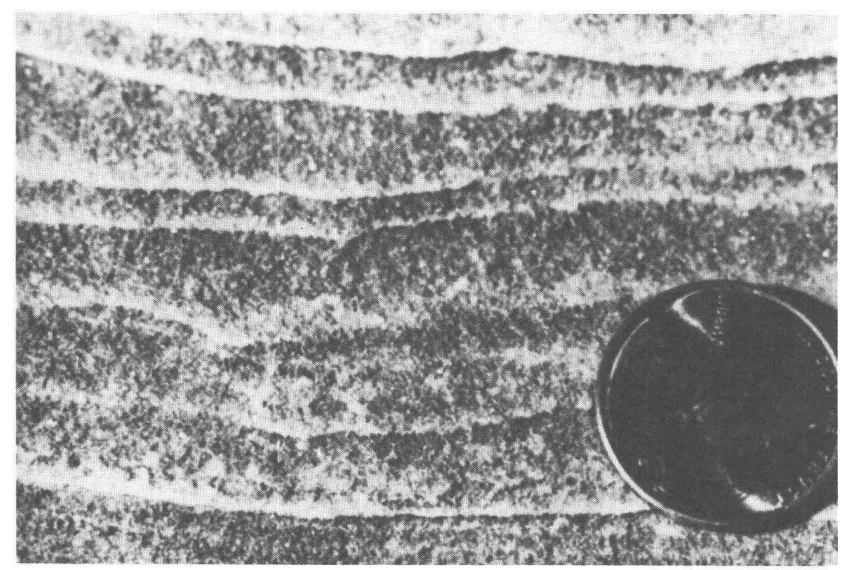

Figure 10. Inversely graded laminations produced by ripple migration, dune deposit, base of Shafer Trail.

High-index ripples, R.I. $>15$, oriented parallel to the dip direction of the foresets, are commonly observed on exposed slip faces (fig. 12). High-index ripples on slip faces are formed either by deflection of wind over the dune surface or by a temporary change in wind direction (Bigarella, 1972). Strata produced by migrating wind ripples are distinctly laminated and inversely graded (Fryberger and Schenk, 1981), and are characterized by a "pin-striped" appearance (fig. 13).

Rare raindrop impressions with raised rims and depressed centers are found preserved on exposed slip face surfaces. Raindrop impressions, although not definitive

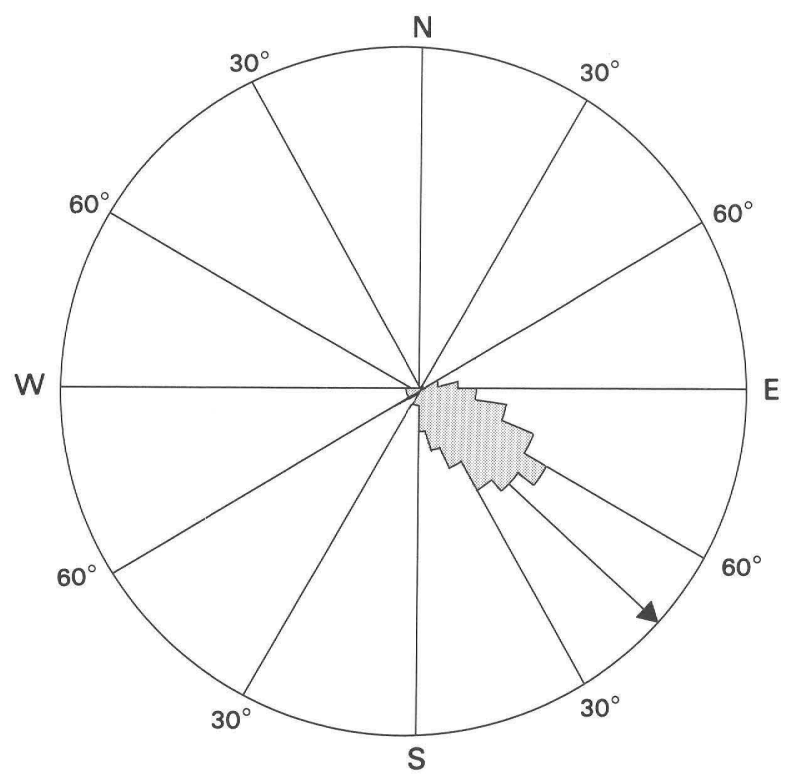

Average mean dip direction $=\mathrm{S} 47 \mathrm{E}$

Total number of measurements $=707$

Figure 11. Equal-area rose diagram of crossbedding dip direction measurements.

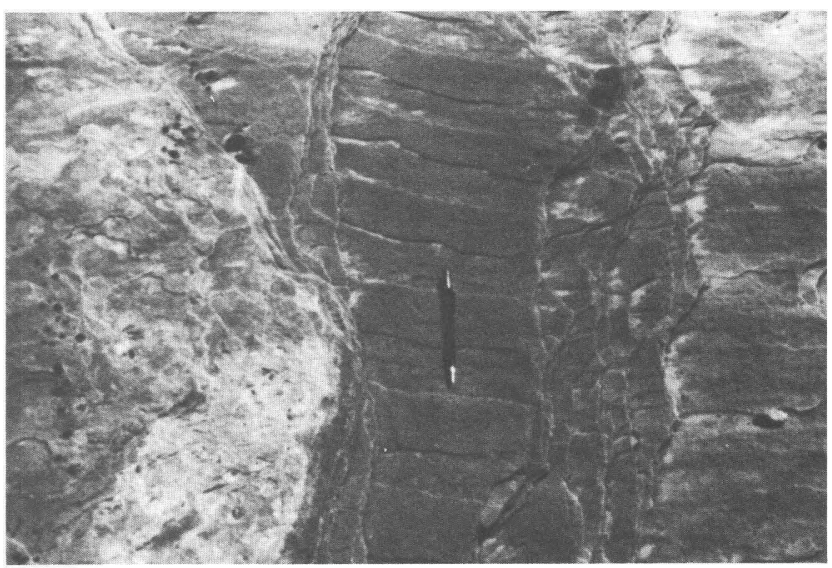

Figure 12. High-index ripples, dune deposit, base of Queen Anne Bottom section. Ripple wavelength is approximately $13 \mathrm{~cm}$ and ripple height is approximately 3 $\mathrm{mm}$.

proof of eolian deposition, do indicate subaerial exposure.

Colors of the White Rim dune deposits are commonly white, very light gray, or yellowish gray. These dune sands are generally well to moderately well sorted, generally fine grained but ranging from fine to coarse grained, and subrounded to rounded. The dominant mineral constituent is monocrystalline quartz, and most of the sands would be classified as quartz arenites (Folk, 1974). Many of the coarser quartz grains are frosted. Other major mineral constituents are microcline, polycrystalline quartz of unknown origin, and chert. Trace amounts of zircon, tourmaline, apatite, glauconite, mica, altered iron-titanium oxides, and garnet are also present. Little or no clay was observed in the samples examined. These sandstones are commonly calcite cemented. Silica cement, in the form of quartz overgrowths, is also present and has altered the original roundness of some quartz grains.

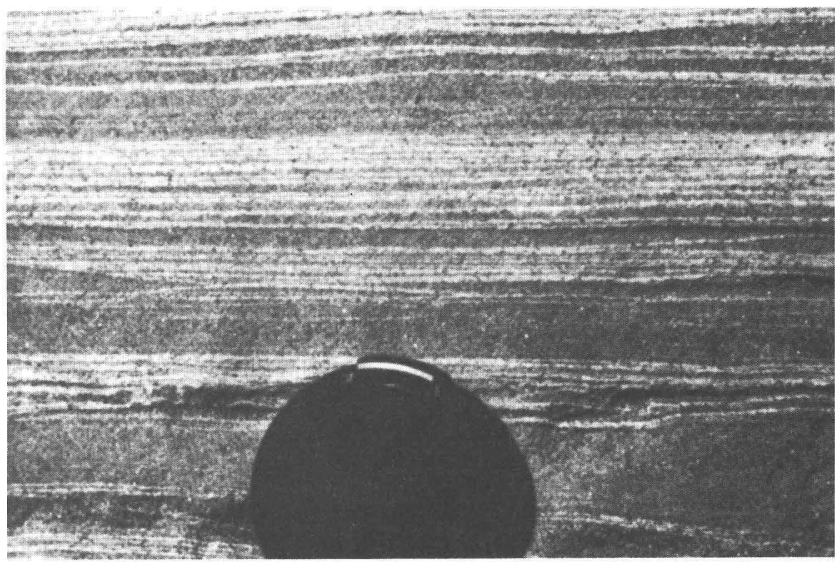

Figure 13. Pin-striped bedding formed by ripple migration, dune deposit, base of Shafer Trail. 


\section{Interdune Deposits}

An interdune is defined as an area either enclosed or partially enclosed by dunes. Interdune deposits are sediments that occur in the interdune areas and may record either deflationary or depositional processes. Recent work by Ahlbrandt and Fryberger (1981, 1982) and Kocurek (1981) on modern and ancient eolian systems has recognized the relationship of water content to the types of sedimentary structures formed in interdunes. They have informally subdivided depositional and deflationary interdunes into dry, damp, wet, and evaporite on this basis. Fryberger and others (1983) and Kocurek (1981) listed the sedimentary structures common to each type of interdune setting. Also, like all depositional environments, interdune environments are not static, and any single interdune deposit may reflect a variety of conditions. Deflationary and depositional interdunes that formed under varying degrees of wetness are recognized in the White Rim.

Generally, White Rim interdune deposits are thin and lenticular, a geometry that may be related to the unimodal wind regime in which the White Rim sand was deposited. According to Ahlbrandt and Fryberger (1981), interdune geometries appear to be closely related to wind regime, and interdunes from unimodal wind regimes are thought to be thin and lenticular.

Dry deflationary interdune deposits are common in the White Rim and occur as thin erosional lags between crossbed sets (fig. 14). Their average thickness is less than $0.5 \mathrm{~m}$; they are lenticular and appear to be roughly horizontally stratified. The basic mineralogy of these deposits is similar to the dune deposits, but in general they are darker colored, coarser grained, and more poorly sorted than the surrounding dune sands. Samples taken from these lag deposits commonly have a bimodal grain size distribution and show textural inversion (fig. 15). Folk (1968) described textural inversion as the occurrence of large, well-rounded quartz grains "floating" within finer, more angular quartz grains, and considered the phenomenon to be a product of deflationary processes.

Other White Rim interdune deposits appear to be closely related to water table fluctuations and are most likely the result of a combination of damp or evaporitic depositional processes. These interdune deposits commonly have wavy, discontinuous, horizontal laminations

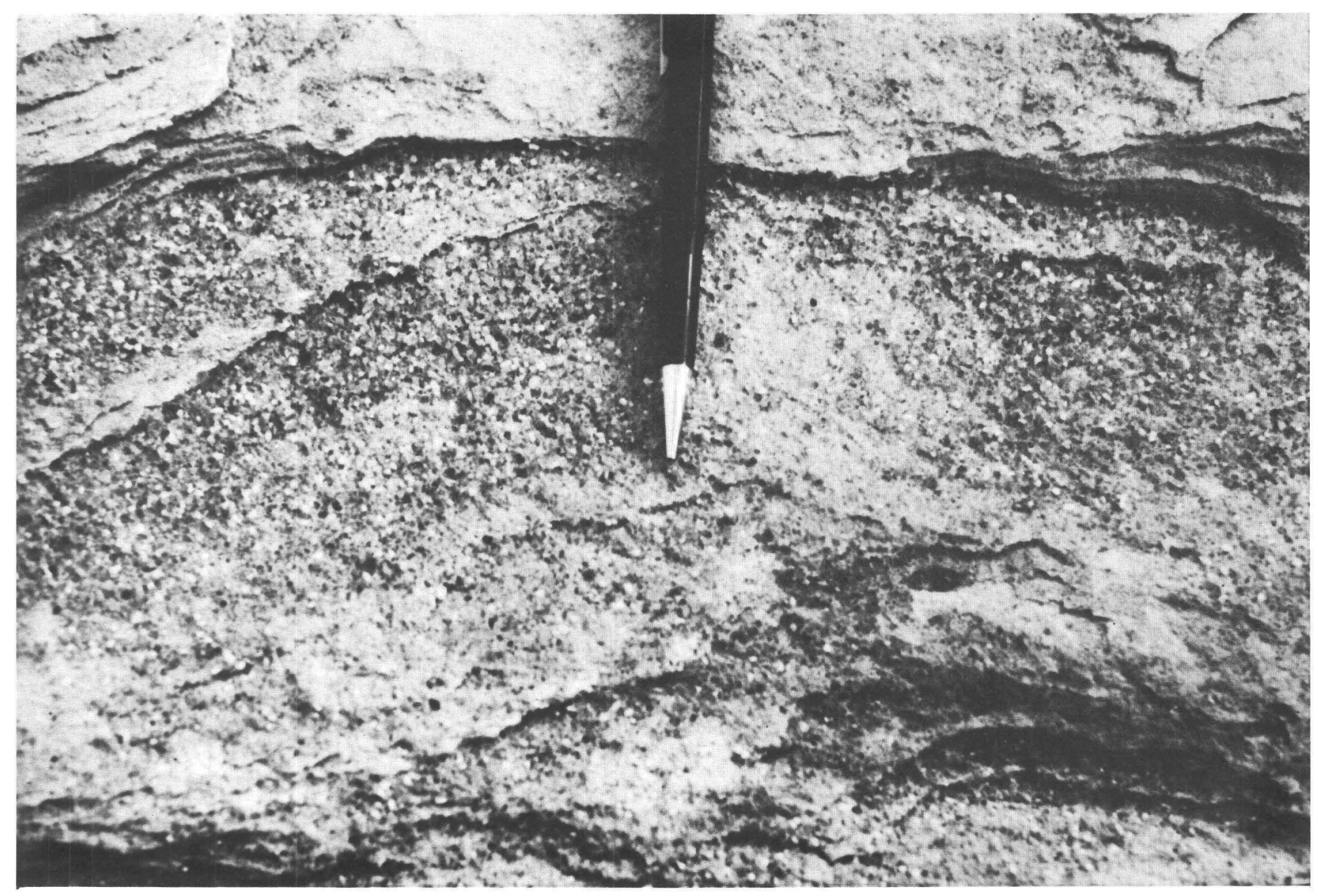

Figure 14. Bimodal erosional lag, dry deflationary interdune deposit, Unknown Bottom. 


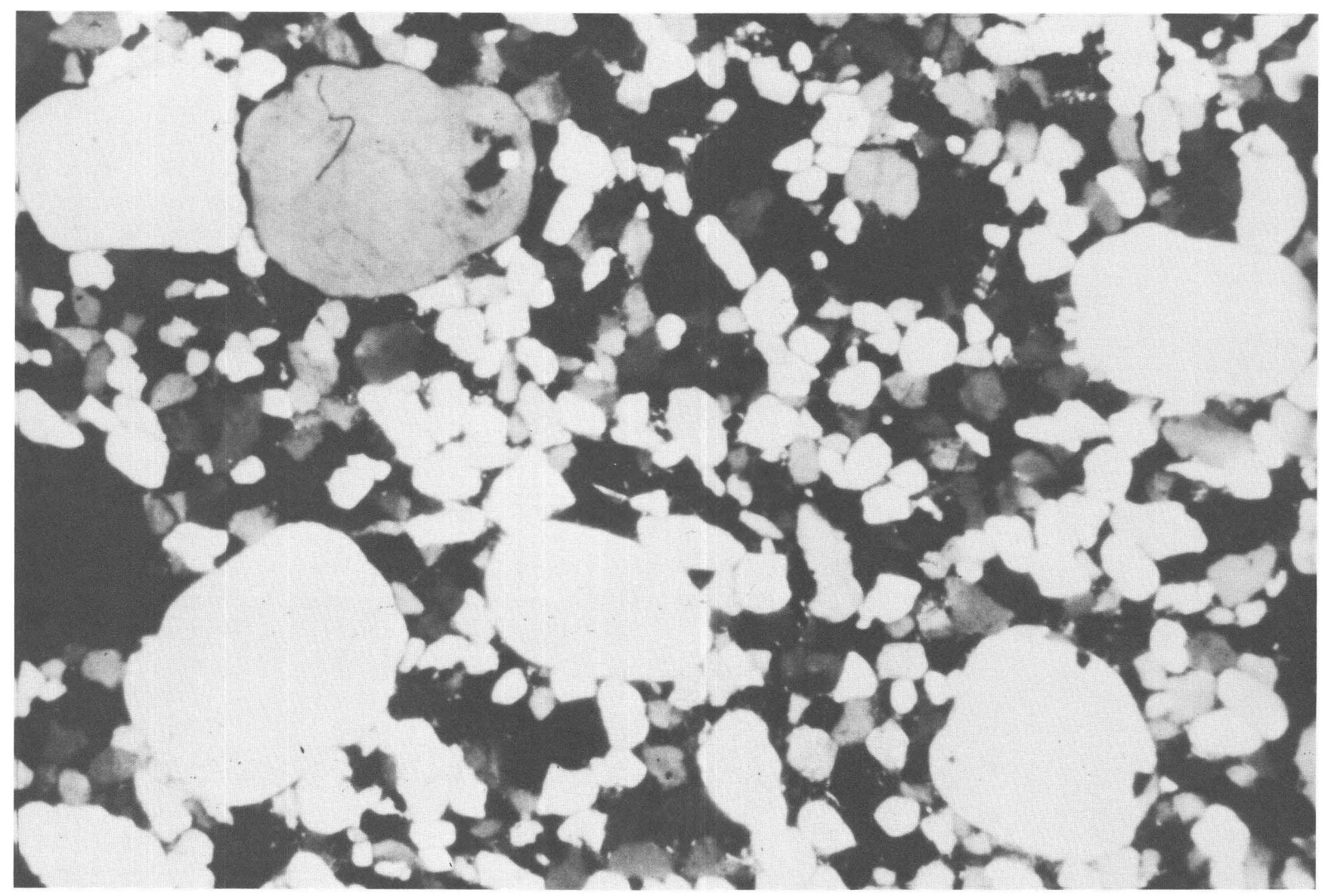

Figure 15. Textural inversion, dry deflationary interdune deposit, Beaver Bottom section. (Field of view approximately $5.5 \mathrm{~mm}$, polars crossed)

that have been disrupted by either biological activity or diagenetic changes (fig. 16). Primary sedimentary structures in the interdune deposits are commonly discernible only on bedding surfaces. Two distinctive interdune sedi- mentary structures recognized in the White Rim are adhesion ripples and desiccation polygons. Adhesion ripples form when sand is blown across a damp surface, commonly grow into the wind, and are strongly asymmetrical

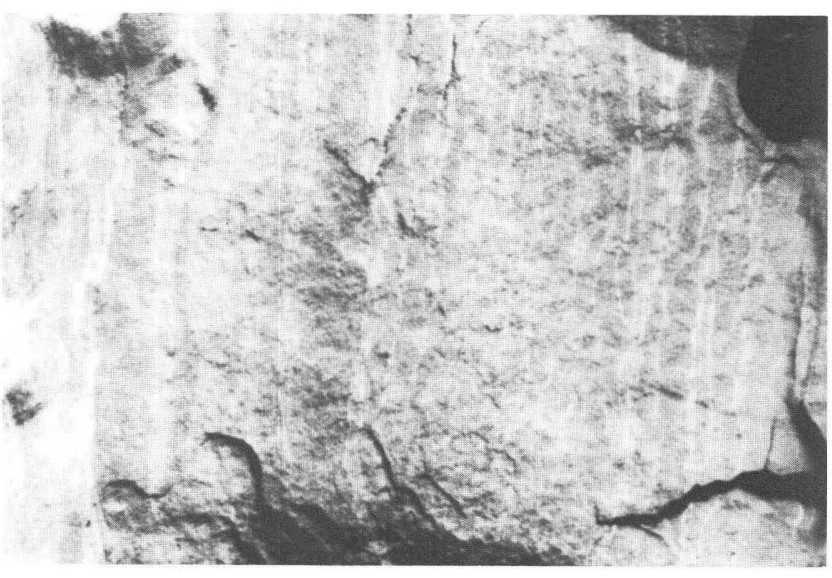

Figure 16. Wavy, horizontally laminated bedding, depositional interdune, base of Shafer Trail.

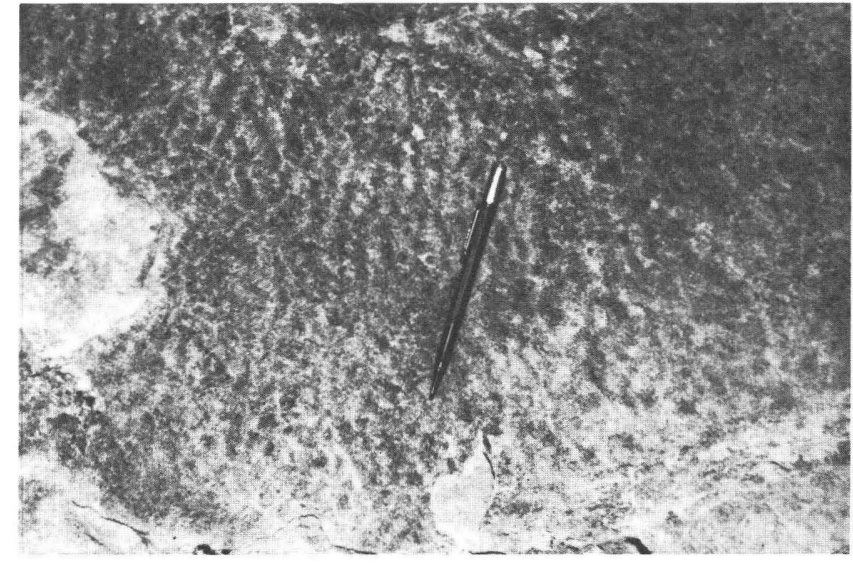

Figure 17. Plan view of adhesion ripples, depositional interdune, near Washer Woman section. 
(Reineck and Singh, 1975). Even minor shifts in wind direction affect these ripples, creating an irregular, bumpy bedding surface (fig. 17). Generally, sets of adhesion ripple strata are less than $0.5 \mathrm{~m}$ thick in the White Rim, but can reach thicknesses of over $1 \mathrm{~m}$. According to Ahlbrandt and Fryberger (1981), a rising water table may account for the thicker accumulations of adhesion ripple strata.

Some White Rim interdune surfaces are covered with 5-sided polygons (fig. 18) that have widths of up to $0.7 \mathrm{~m}$ and occur in almost totally sand-sized material. These polygons may represent relict sait-ridge structures and indicate occasional evaporitic conditions in the interdune areas. Initially, capillary evaporation of saline groundwater creates a salt crust, and the polygons later form as the result of alternating periods of desiccation and deposition (Glennie, 1970; Ericksen and Stoertz, 1978). The sand that forms these polygons often is stained reddish brown. This staining may be a result of the exposure of salt-encrusted sand to the sun during salt-ridge formation (Fryberger and others, 1983).
In many ancient and modern interdune areas, both plant and animal burrows are common (Fryberger and others, 1983). No distinct burrows of any kind were observed in the White Rim interdunes. Bioturbation is occasionally present (fig. 19), which gives the sediment a characteristic mottled, homogeneous appearance (Friedman and Sanders, 1978).

The basic mineralogy and texture of these interdune deposits are similar to the dune deposits, but there are some differences. Their color is normally darker than the dune sands, ranging from yellowish orange to brownish orange, and they commonly have a banded appearance (fig. 16). Concentrations of heavy mineral grains in the laminations are common. Dolomite is present in the interdune sands and occurs as individual, euhedral to subhedral rhombohedrons that are heavily iron stained. The rhombohedrons commonly form distinct layers, often appear abraded (fig. 20), and are probably of secondary origin (Scholle, 1978).

Few biological constituents were observed in the White Rim. A crinoid ossicle was identified from a

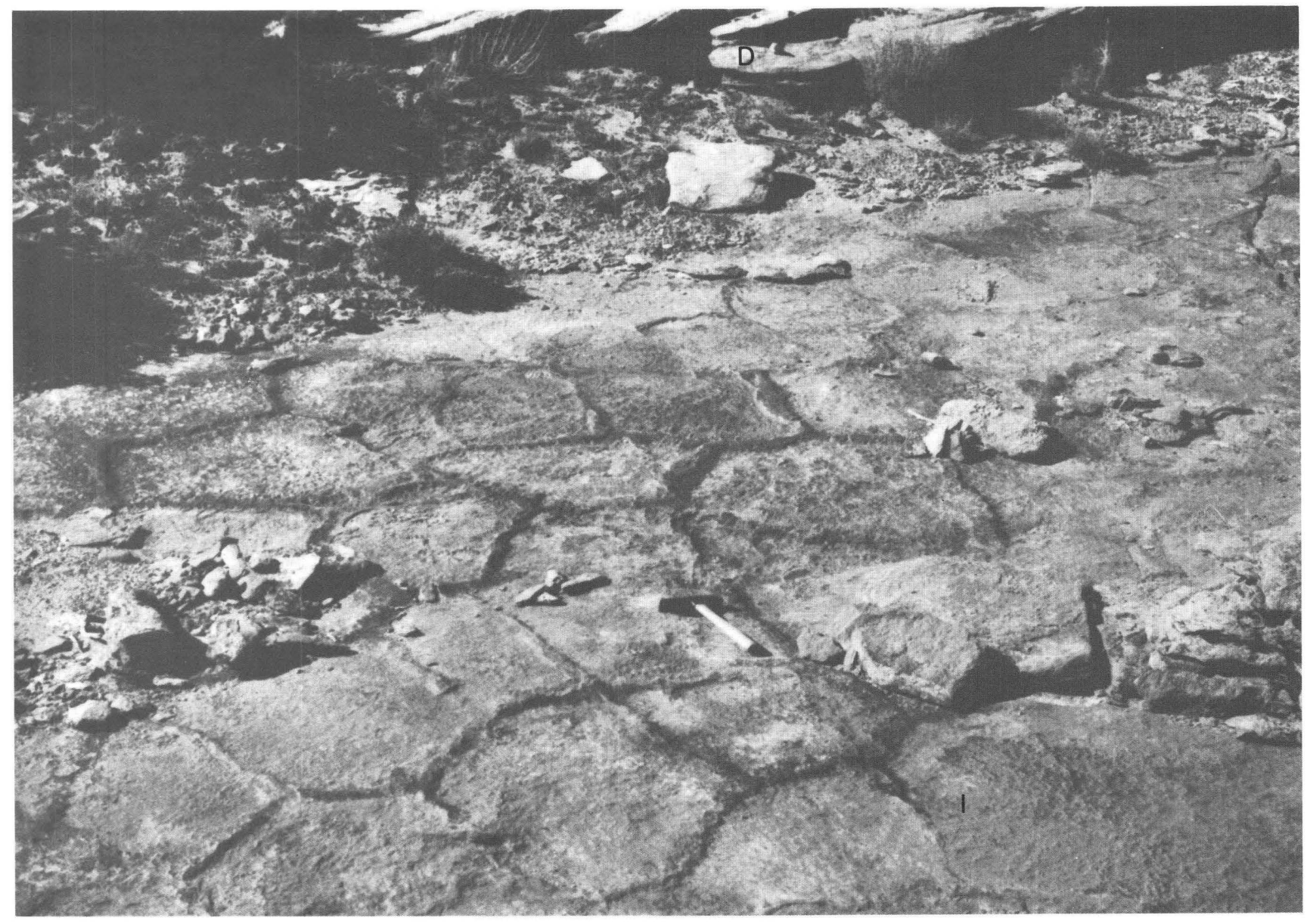

Figure 18. Plan view of desiccation polygons, depositional interdune (I), overlain by dune deposit (D), Musselman Arch. 


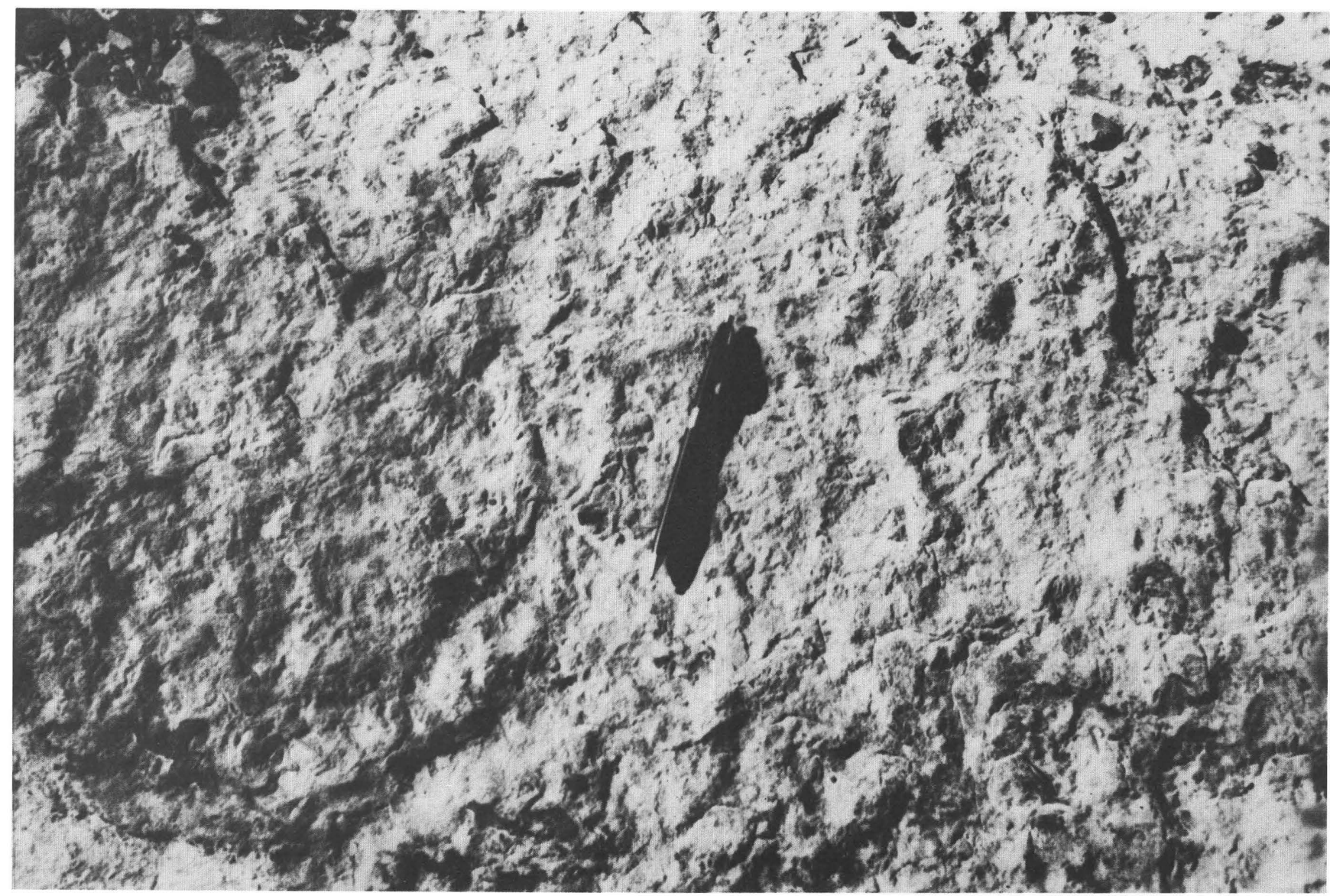

Figure 19. Bioturbation, bedding plane surface, depositional interdune deposit, base of Shafer Trail.

coarse-grained zone near the base of the White Rim in the White Crack section (fig. 3). The ossicle is well preserved, showing single-crystal extinction, which is typical of echinoderm grains. Fecal pellets were also observed in a number of interdune samples and are commonly encased in dolomite rhombohedrons.

\section{Sabkha Deposits}

In the eastern part of the study area, the entire basal White Rim consists of flat-bedded sandstone that has most of the characteristics of depositional interdune deposits. This may represent an ancient sabkha deposit. Sabkhas, although similar to interdunes, are more aerially extensive than interdunes and are related to a stable and continued rise in the water table (Fryberger and others, 1983). Johnson and others (1978) defined inland sabkhas as evaporitic, commonly salt-encrusted, saline flats underlain by clay, silt, and sand. The development and distribution of inland sabkhas are controlled by topography and fluctuations in the local water table. Also, sabkhas can be either detrital dominant or evaporite dominant. The White Rim sabkha consists largely of clastic material, and no evidence of extensive evaporite minerals is present; thus the sabkha would be classified as detrital dominant (Fryberger and others, 1983). One feature observed in the White Rim that has been described in modern detrital-dominant sabkhas (Fryberger and others, 1983) is bedding with a banded appearance (fig. 16). This light-dark color banding may result from the intercalation of light-colored sand of ripple-produced strata and reddish-brown stained sand of salt-ridge structures.

Several factors contributed to the location and development of this sabkha. The sabkha location coincides with the White Rim's eastern pinchout, which Baars (1979) considered to be related to early movement of the Monument upwarp. Thus, the Monument upwarp created a topographic barrier to the east. The sabkha was also protected to the west by the main White Rim dune complex. In some modern eolian systems, sabkhas commonly occur down wind of the major dune complex (Fryberger and others, 1983). Growth of the sabkha most likely resulted from a slow but steadily rising water table and continued accumulation of sediment. 


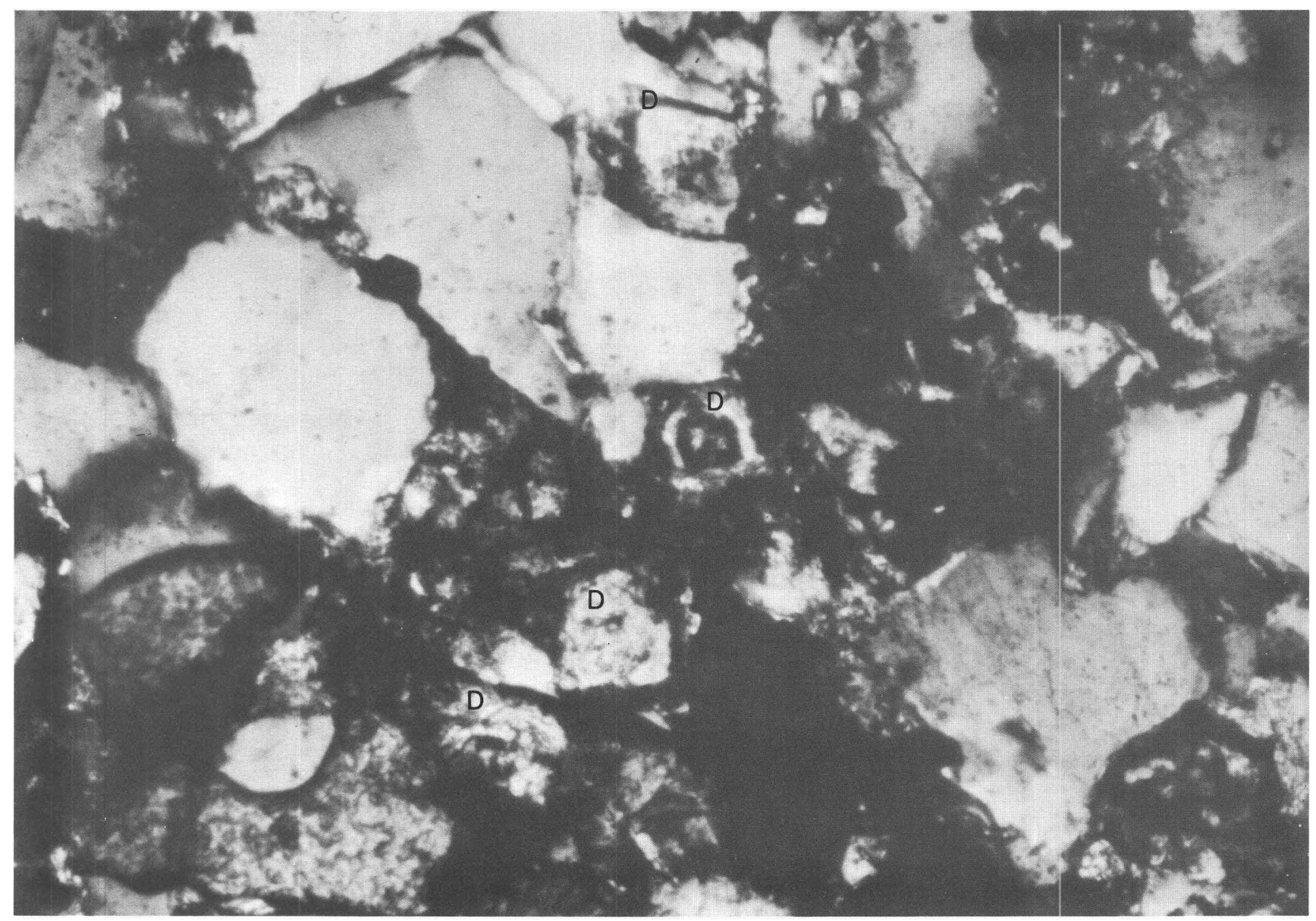

Figure 20. Dolomite rhombohedrons (D) of secondary origin, depositional interdune, Buck Canyon section. (Field of view approximately $0.7 \mathrm{~mm}$, polars crossed)

\section{Relationship of Dune and Interdune Deposits}

Figure 21 is a schematic fence diagram compiled from the measured sections, showing the regional stratigraphic relationships and distribution of dune, interdune, and sabkha deposits. In the eastern part of the study area, the entire basal White Rim may be a sabkha deposit, reaching a thickness of almost $6 \mathrm{~m}$. Depositional interdunes occur as distinct, thin, lenticular units within the dune deposits (fig. 22). To the northwest, in sections $\mathrm{QAB}$ and $\mathrm{BB}$ (fig. 3), no depositional interdunes were observed. Sabkha and depositional interdune deposits both require damp or wet conditions during their formation. Distribution of these deposits in the White Rim was probably closely related to the water table variations. The location of the sabkha deposit and the prevalence of the depositional interdunes in the eastern part of the study area suggest the water table was shallower in this area. Dry deflationary interdune deposits, on the other hand, occur throughout the study area, but are more common in the western part. These deposits were most likely independent of the water table fluctuations and were related to dune migration during White Rim deposition.

\section{DEPOSITIONAL SETTING}

Figure 23 is a schematic diagram of the depositional setting of the White Rim Sandstone Member. Dune fields can be broadly grouped as either coastal or inland (McKee and Bigarella, 1979b). Several different lines of evidence suggest the White Rim Sandstone Member was deposited in a coastal setting. These are (1) Permian paleogeography, (2) stratigraphic relationships, (3) geometry of the White Rim sand body, (4) dune form, and (5) certain petrologic features.

The White Rim Sandstone Member was deposited during late Leonardian to early Guadalupian time according to Baars and Seager, (1970). Figure 24 shows the proposed Early Permian paleogeography of Canyonlands and surrounding areas. West of Canyonlands was a broad, stable shelf, and to the east, the positive Uncompahgre highlands and Monument upwarp. The shoreline was to the west, running approximately north-south, and Canyon- 


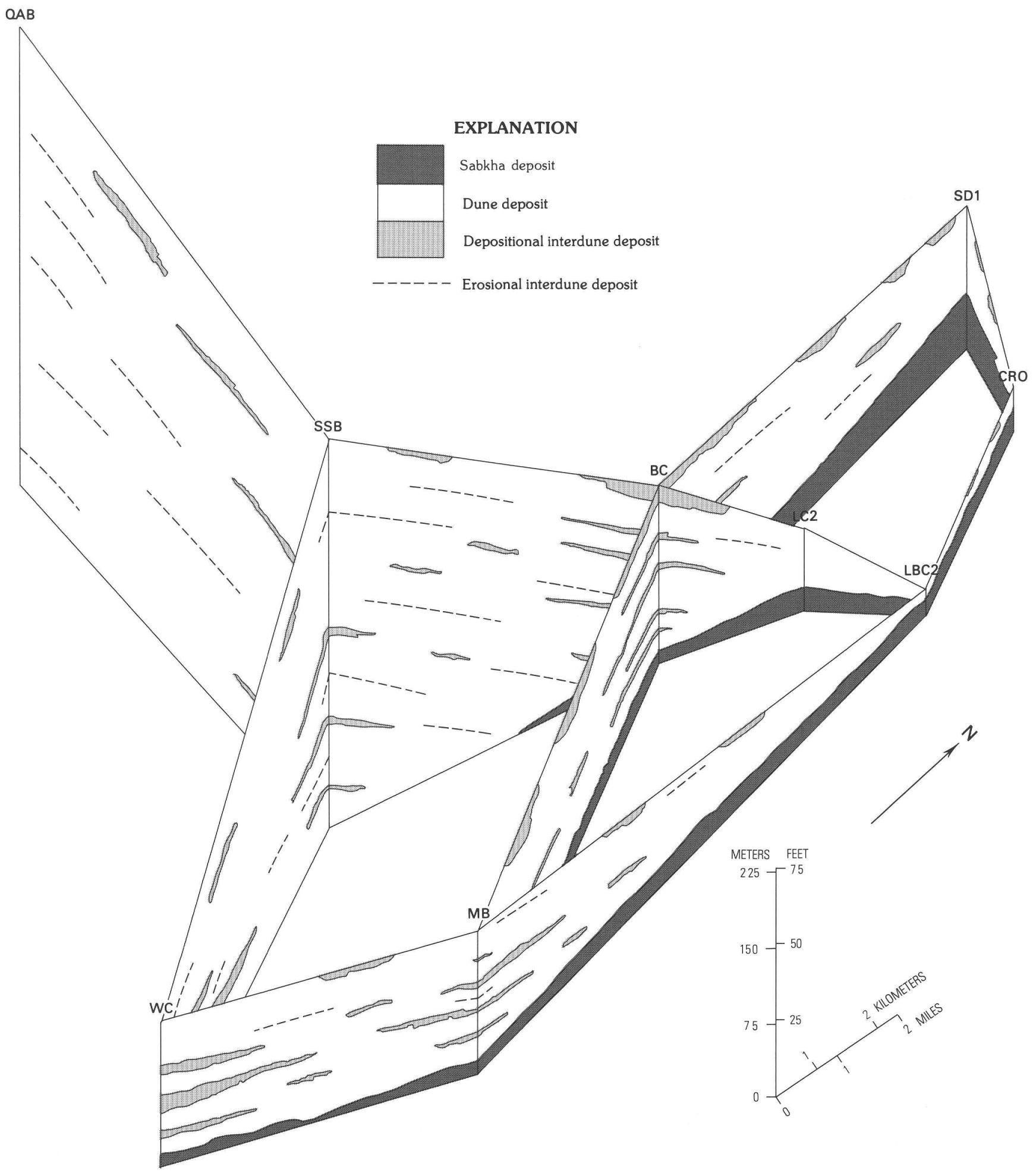

Figure 21. Schematic fence diagram White Rim Sandstone Member dune, interdune, and sabkha deposits.

lands was situated in an active coastal plain area exposed to both marine and nonmarine processes. The proposed paleomagnetic equator during the Permian was to the north. Canyonlands was at approximately $5^{\circ} \mathrm{S}$. latitude, and much of North America was in the Southeast Trade
Winds Belt (Opdyke and Runcorn, 1960; Dott and Batten, 1976). Northwest to southeast winds deposited the White Rim sand even though the area was in the Southeast Trade Wind Belt. This northwest to southeast wind pattern may represent onshore winds, resulting from differential cool- 


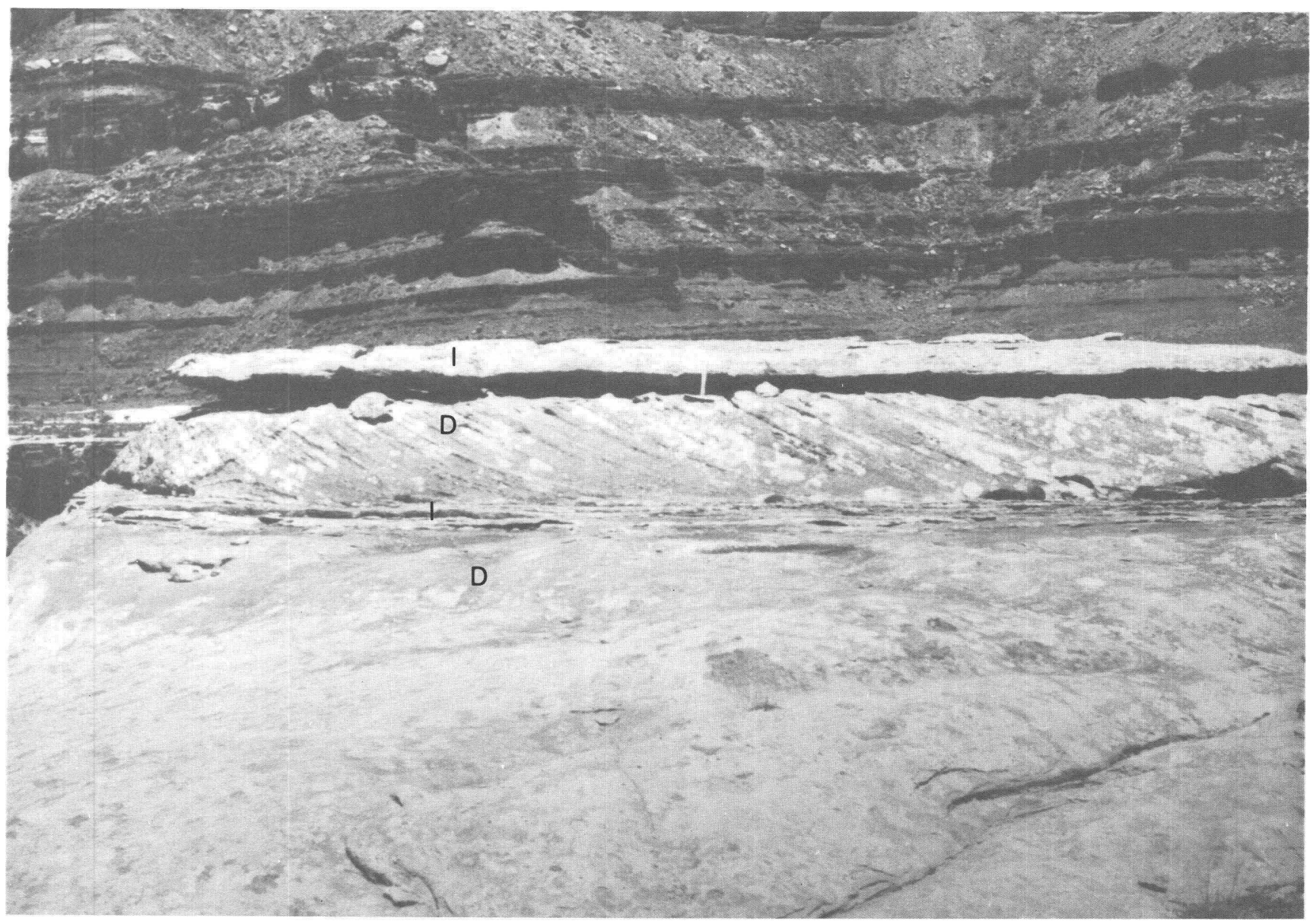

Figure 22. Interbedded dune (D) and depositional interdune (I) deposits, Lathrop Canyon 2 section.

ing and warming between land and sea. According to Goldsmith (1978), an onshore wind pattern commonly is dominant regardless of the general wind circulation pattern. Also, this southerly wind pattern was common in the Permian and is evident in other proposed eolian units in the region, including the DeChelly Sandstone Member of the Cutler Formation and the Coconino Sandstone (Poole, 1962).

Stratigraphic relationships of the White Rim imply a coastal setting. It abruptly pinches out eastward into the nonmarine Organ Rock Member. Westward it apparently grades into the largely marine upper member of the Toroweap Formation and the gamma member of the Kaibab Limestone. Unfortunately, much of the westernmost White Rim occurs in the subsurface, and little information is available. The transition between marine and eolian environments may begin just west of Canyonlands, in the Elaterite Basin area (fig. 1), where the uppermost portion of the White Rim contains a thin, veneer-like unit with well-developed but localized oscillation ripples (Baars and Seager, 1970; Chan and Huntoon, 1984). Chan

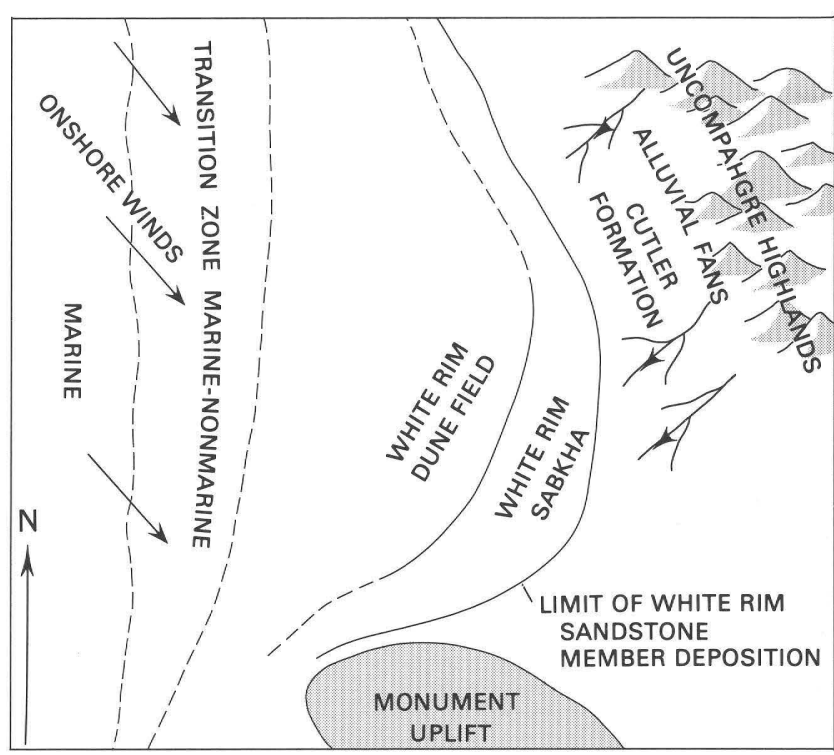

Figure 23. Schematic diagram of White Rim Sandstone Member depositional setting. 


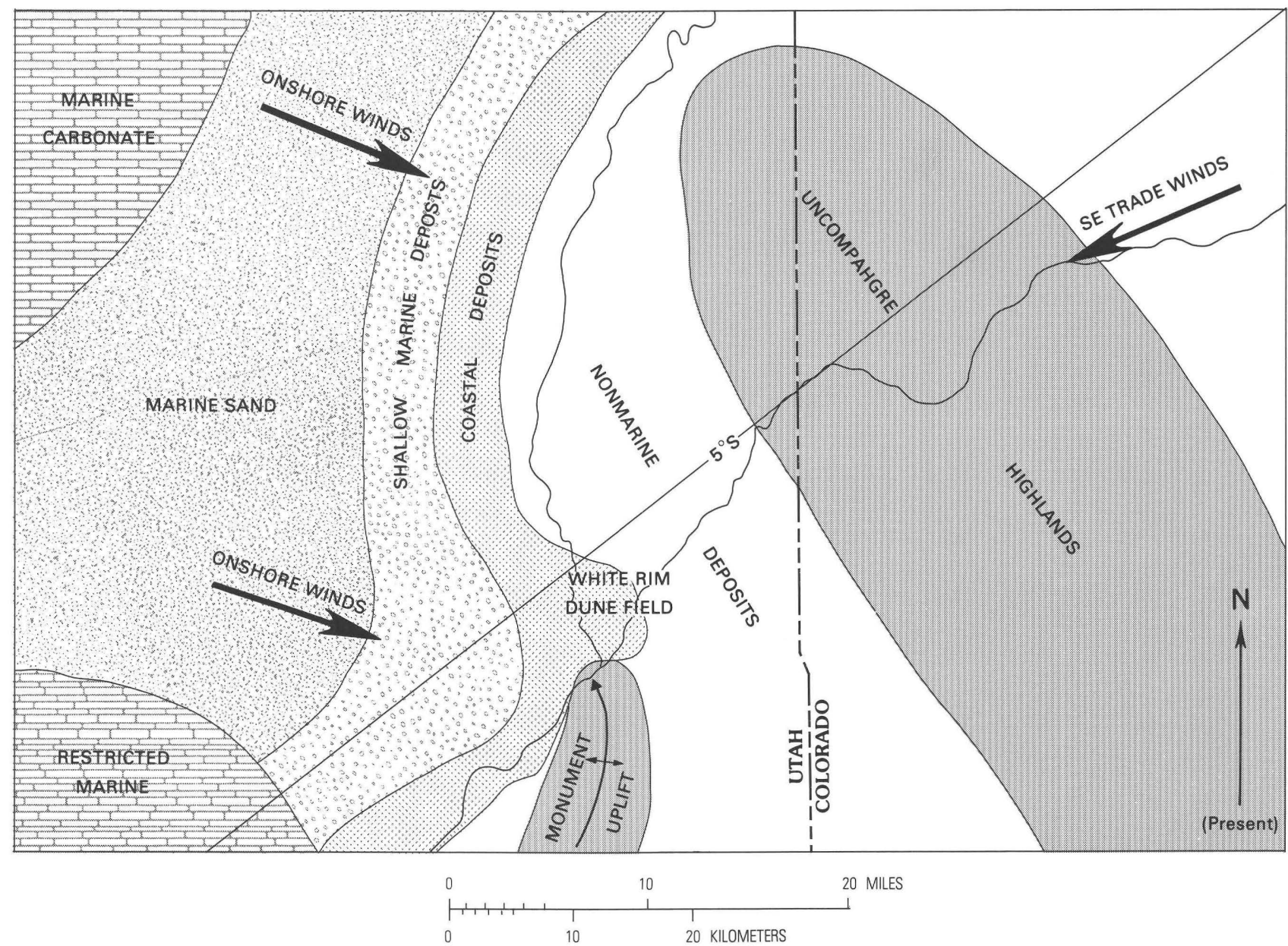

Figure 24. Paleogeographic map of Canyonlands National Park and surrounding area: late Wolfcampian-early Leonardian time. (Modified from Hallgarth, 1967b)

and Huntoon (1984) observed coarse-grained sandstones with chert pebbles and abundant fluid escape structures in this uppermost unit and considered it to represent a reworked zone, formed during a marine transgression. Also, northwest of the study area near the San Rafael uplift (fig. 1), the top of a unit identified as White Rim is bioturbated and contains identifiable marine fossils (Orgill, 1971).

The geometry of dune sands is probably closely related to their depositional setting (McKee and Bigarella, 1979b). An inland dune field tends to form an extensive, tabular or wedge-shaped sand sheet. A coastal dune field can form a more narrow, elongate sand sheet. The White Rim, an elongate, narrow, northwest-southeast sand body, is more characteristic of a coastal dune field. Unimodal crossbedding measurements indicate the White Rim dune form was most likely barchanoid or transverse ridges (fig. 8 ), which are common coastal dune forms in unvegetated areas (Goldsmith, 1978).

Coastal dune sands are essentially beach sediments that have been reworked and piled up by the wind. Sev- eral petrologic features of the White Rim suggest the proximity of a beach, the most important of which is the presence of glauconite. Trace amounts of well-rounded, unaltered glauconite pellets (fig. 25) were observed in thin sections of samples collected from all the measured sections, and occur in both dune and interdune deposits. Glauconite is the name given to a variety of dull-green, earthy, iron-rich clay minerals of the mica group that commonly form under local reducing conditions in shallow-marine water (Weaver and Pollard, 1973). The presence of glauconite in a sediment usually indicates a marine depositional environment, for it rarely survives erosion and redeposition in nonmarine environments (Triplehorn, 1966). The occurrence of glauconite throughout the White Rim suggests proximity to a marine environment. Along with the glauconite, the crinoid fragment and the relative enrichment of heavy minerals in the interdune deposits may also indicate a nearby beach. According to Potter (1967), skeletal debris, heavy mineral concentrates, and small amounts of glauconite are common constituents of many beach sediments. 


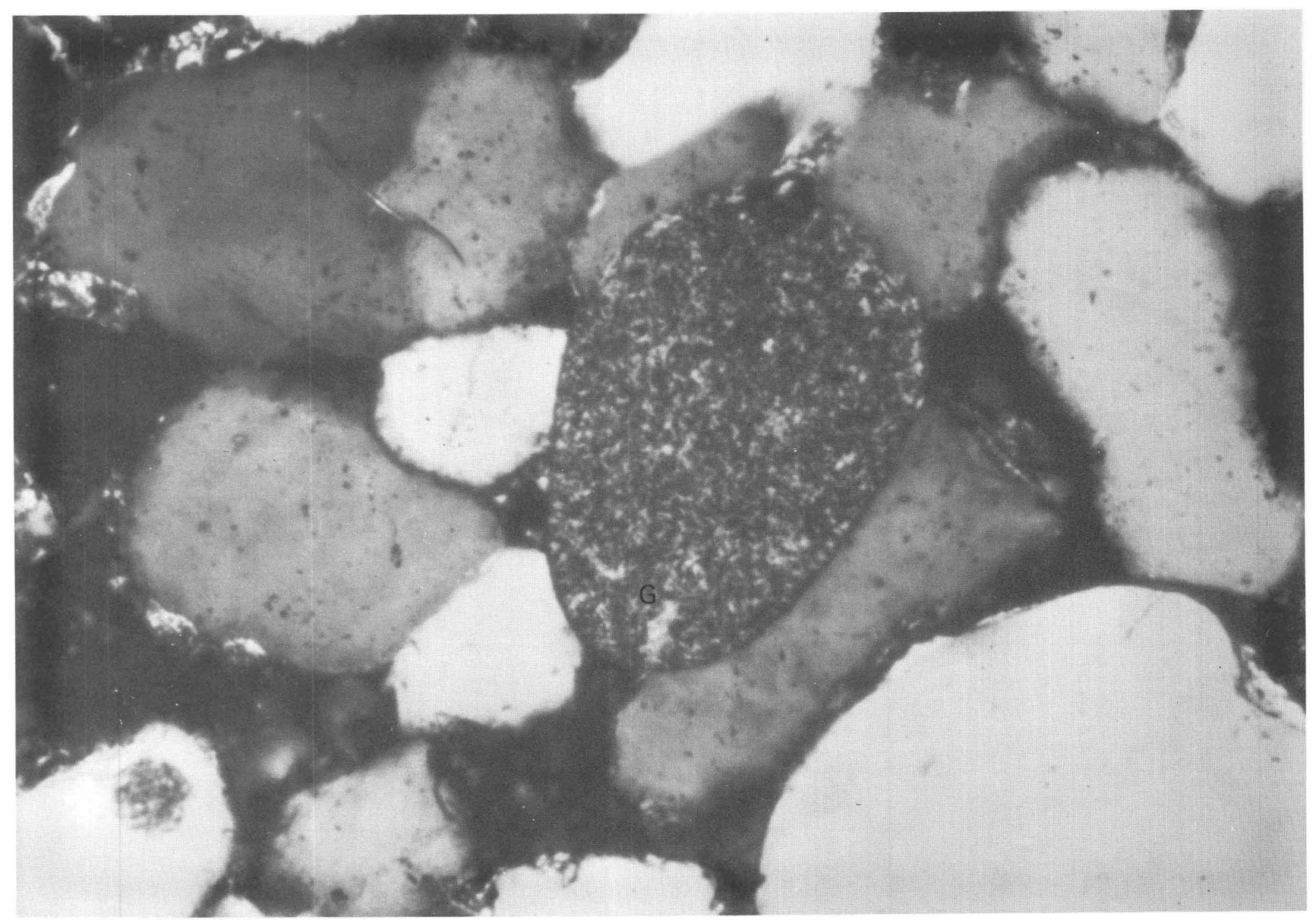

Figure 25. Glauconite pellet (G), dune deposit, Beaver Bottom section. (Field of view approximately $0.7 \mathrm{~mm}$, polars crossed)

\section{ECONOMIC GEOLOGY}

The White Rim Sandstone Member has major petroleum reserves and contains the largest tar-sand deposit in the United States (Ritzma, 1980). Campbell and Ritzma (1979) have estimated the tar sands may contain up to 16 billion barrels of oil in place. These deposits are found west of the study area in the Elaterite Basin region (fig. 1), and are mostly either part of national parkland or proposed wilderness areas. The oil is trapped by the updip pinchout of the White Rim on the northwest plunge of the Monument upwarp (Campbell and Ritzma, 1979). According to Baars and Seager (1970), the most likely source for petroleum was the Permian Kaibab Limestone because of its stratigraphic position adjacent to the White Rim.

There is some evidence suggesting that petroleum migrated through the White Rim in the study area. The normally reddish-brown sandstone unit overlying the White Rim is bleached at sections BB and BC (fig. 3), indicating reduction by migrating petroleum. Also, a number of White Rim samples contain possible accumulations of dead oil (Steele-Mallory, 1981b, 1982).

\section{CONCLUSIONS}

1. The White Rim Sandstone Member of the Permian Cutler Formation in Canyonlands National Park, Utah, was deposited in an eolian system.

2. The White Rim contains three types of eolian deposits-dune, interdune, and sabkha - which can be differentiated on the basis of sedimentary structures and petrologic features.

3. Distinctive sedimentary structures of the dune deposits are large-scale, unidirectional, tabular planar crossbed sets; high-index ripples oriented parallel to dip direction of the foresets; and raindrop impressions. A strongly unidirectional, northwest to southeast orientation of the crossbedding suggests the dune forms were barchanoid or transverse ridges. The dune deposits are basically light-colored, fine-grained, 
well- to moderately well sorted quartz arenites with little clay material.

4. Interdune deposits resulting from both deflationary and depositional processes and formed under varying degrees of wetness are present. Most of the interdune deposits occur as thin, discontinuous units intercalated with the dune deposits. Dry deflationary deposits occur as darker colored, thin, lenticular, bimodal, coarse-grained lags between crossbed sets. Other interdune deposits appear to have formed by a combination of damp and evaporitic depositional processes. Characteristic sedimentary structures of these interdunes are wavy, discontinuous, horizontally laminated bedding with dark- and light-color banding; adhesion ripples; bioturbation; and desiccation polygons, which may represent relict salt ridge structures. Their basic texture and mineralogy are similar to the dune deposits, but the depositional interdunes contain abundant euhedral to subhedral dolomite rhombohedrons, fecal pellets, a fossil fragment, and concentrations of heavy mineral grains in laminations.

5. A detrital-dominant, inland sabkha formed downwind of the main White Rim dune field. This can be seen in the eastern part of the study area, where the entire lower portion of the White Rim is flat-bedded sandstone and has most of the characteristics of depositional interdune deposits. Location of this sabkha was topographically controlled by early movement of the Monument upwarp, and grew as the result of a stable and slowly rising water table.

6. The White Rim dune field was deposited in a coastal setting by northwest-to-southeast onshore winds during a period of marine transgression. Evidence for a coastal setting includes Permian paleogeography, stratigraphic relationships, geometry of the sand body and dune form, and certain petrologic features such as glauconite pellets, a crinoid fragment, and heavy mineral concentrations.

\section{REFERENCES CITED}

Ahlbrandt, T. S., and Fryberger, S. G., 1981, Sedimentary features and significance of interdune deposits, in Ethridge, F. G., and Flores, R. M., eds., Nonmarine depositional environments: Models for exploration: Society of Economic Paleontologists and Mineralogists, Special Publication no. 31, p. 293-314.

1982, Introduction to eolian deposits, in Scholle, P. A. and Spearing, D., eds., Sandstone depositional environments: American Association of Petroleum Geologists Memoir 31, p. 11-47.

Baars, D. L., 1962, Permian System of the Colorado Plateau: American Association of Petroleum Geologists Bulletin, v. 46, no. 2, p. 149-218.

1979, The Permian System, in Baars, D. L., ed., Permianland: Four Corners Geologic Society Guidebook, Ninth Field Conference, p. 1-6.
Baars, D. L., and Molenaar, C. M., 1971, Geology of Canyonlands and Cataract Canyon: Four Corners Geologic Society Sixth Field Conference, Cataract Canyon River Expedition, $99 \mathrm{p}$.

Baars, D. L., and Seager, W. R., 1970, Stratigraphic control of petroleum in White Rim Sandstone (Permian) in and near Canyonlands National Park, Utah: American Association of Petroleum Geologists Bulletin, v. 54, no. 5, p. 709-718.

Baker, A. A., 1946, Geology of the Green River Desert-Cataract Canyon region, Emergy, Wayne and Garfield Counties, Utah: U.S. Geological Survey Bulletin, 951, 122 p.

Baker, A. A., and Reeside, Jr., J. B., 1929, Correlation of the Permian of southern Utah, northern Arizona, northwestern New Mexico, and southwestern Colorado: American Association of Petroleum Geologists Bulletin, v. 13, no. 11, p. 1413-1448.

Bigarella, J. J., 1972, Eolian environments: Their characteristics, recognition, and importance, in Rigby, J. R. and Hamblin, W. K., eds., Recognition of ancient sedimentary environments: Society of Economic Paleontologists and Mineralogists Special Publication no. 1, p. 12-62.

Blakey, R. C., 1979, Lower Permian stratigraphy of the Colorado Plateau, in Baars, D. L., ed., Permianland: Four Corners Geologic Society Guidebook, Ninth Field Conference, p. 115-129.

Campbell, J. A., 1980, Lower Permian Depositional System, Northern Uncompahgre basin, in Baars, D. L., ed., Permianland: Four Corners Geologic Society Guidebook, Ninth Field Conference, p. 13-21.

Campbell, J. A., and Ritzma, H. R., 1979, Geology and petroleum resources of the major oil-impregnated sandstone deposits of Utah: Utah Geological and Mineralogical Survey Special Publication 50, $24 \mathrm{p}$.

Campbell, J. A., and Stanesco, J. E., 1983, Stratigraphy and depositional environments of the Cedar Mesa Member of the Cutler Formation, southeastern Utah [abs.]: Geologic Society of America Abstracts with Programs, p. 333.

Chan, M. A., and Huntoon, J. F., 1984, Complex interaction of eolian and marine sedimentation in Permian White Rim Sandstone, Elaterite Basin, Southeast Utah [abs.]: American Association of Petroleum Geologists Bulletin, v. 68, no. 7, p. 934-935.

Cheevers, C. W., and Rawson, R. R., 1979, Facies analysis of the Kaibab Formation in northern Arizona, southern Utah and southern Nevada, in Baars, D. L., ed., Permianland: Four Corners Geologic Society Guidebook, Ninth Field Conference, p. 105-113.

Dott, R. B., Jr., and Batten, R. L., 1976, Evolution of the Earth: McGraw-Hill Incorporated, 504 p.

Ericksen, G. E., and Stoertz, G. E., 1978, Solar, salar structures, in Fairbridge, R. W. and Bourgeois, J., eds., The encyclopedia of sedimentology: Encyclopedia of Earth Sciences, v. VI, Dowden, Hutchinson and Ross, Incorporated, p. 636-640.

Fassett, J. E., and Wengerd, S. A., eds., 1975, Canyonlands country: Four Corners Geologic Society Guidebook, Eighth Field Conference, $281 \mathrm{p}$.

Fenneman, N. M, 1928, Physiographic divisions of the United States: Annals of the Association of American Geographers, 3rd. ed. v. 18 , no. 4 , p. $338-342$. 
Folk, R. L., 1968, Bimodal supermature sandstones: Product of the desert floor: International Geologic Congress, 23rd, Prague, Czechoslovakia, 1968, Genesis and classification of sedimentary rocks, Proceeding Section 8, p. 9-32.

1974, Petrology of sedimentary rocks: Hemphill Publishing Company, Austin, Texas, $182 \mathrm{p}$.

Friedman, G. M., and Sanders, J. E., 1978, Principles of sedimentology: John Wiley and Sons, Incorporated, $792 \mathrm{p}$.

Fryberger, S. G., and Schenk, C. J., 1981, Wind tunnel experiments and the origin of eolian strata: Sedimentology, v. 28 , p. 805-821.

Fryberger, S. G., Abdulkader, M. A., and Clisham, T. J., 1983, Eolian dune, interdune, sand sheet, and siliciclastic sabkha sediments of an offshore prograding sand sea, Dhahran area, Saudi Arabia: American Association of Petroleum Geologists Bulletin, v. 67, no. 2, p. 280-312.

Glennie, K. W., 1970, Desert sedimentary environments: Developments in Sedimentology 14: Elsevier Publishing Company, 222 p.

Goldsmith, V., 1978, Coastal dunes, in Davis, R. A., ed., Coastal sedimentary environments: Springer-Verlag, p. 171234.

Hallgarth, W. E., 1967a, Western Colorado, southern Utah and northwestern New Mexico, in McKee, E. D., and others, eds., Paleotectonic investigations of the Permian System in the United States: U.S. Geological Survey Professional Paper 515-I, p. 17-197.

1967b, Parts of Colorado and Utah at a time during deposition of sediments of interval B, in McKee, E. D., and others, Paleotectonic maps of the Permian System: U.S. Geological Survey Miscellaneous Investigation Map I-450, pl. 10.

Heylmun, E. B., 1958, Paleozoic stratigraphy and oil possibilities of the Kaiparowits region, Utah: American Association of Petroleum Geologists Bulletin, v. 42, no. 8, p. 1781-1811.

Hunt, C. B., 1956, Cenozoic geology of the Colorado Plateau: U.S. Geological Survey Professional Paper 279, 99 p.

Hunter, R. E., 1977, Basic types of stratification in small eolian dunes: Sedimentology, v. 24, p. 361-387.

Irwin, C. D., 1971, Stratigraphic analysis of upper Permian and lower Triassic strata in southern Utah: American Association of Petroleum Geologists Bulletin, v. 55, no. 11, p. 19762007.

Johnson, D. H., Kamal, M. R., Pierson, G. O., and Ramsay, J. B., 1978, Sabkhas of eastern Saudi Arabia, in Al-Sayari, S. S., and Zötl, J. G., eds., Quaternary Period in Saudi Arabia: New York, Springer-Verlag, p. 84-93.

Kocurek, G., 1981, Significance of interdune deposits and bounding surfaces in aeolian dune sands: Sedimentology, v. 28, p. $753-780$.

Kocurek, G., and Dott, Jr., R. H., 1981, Distinctions and uses of stratification types in the interpretation of eolian sand: Journal of Sedimentary Petrology, v. 51, no. 2, p. 579-595.

Kunkel, R. P., 1958, Permian stratigraphy of the Paradox basin, in Sanborn, A. F., ed., Guidebook to the geology of the Paradox basin: Intermountain Association of Petroleum Geologists, p. 163-168.
Lohman, S. W., 1974, The geologic story of Canyonlands National Park: U.S. Geological Survey Bulletin 1327, 126 p.

Loope, D. P., 1984, Eolian origin of Upper Paleozioc sandstones, Southeastern Utah: Society of Economic Paleontologists and Mineralogists, v. 54, no. 2, p. 563-580.

Mack, G. H., 1979, Littoral marine depositional model for the Cedar Mesa Sandstone (Permian), Canyonlands National Park, Utah, in Baars, D. L., ed., Permianland: Four Corners Geologic Society Guidebook, Ninth Field Conference, p. 33-37.

McKee, E. D., 1954, Permian stratigraphy between Price and Escalante, Utah, in Intermountain Association of Petroleum Geologists Guidebook 5th Annual Field Conference, Portions of high plateaus and adjacent canyonlands, central and south-central Utah, p. 21-24.

McKee, E. D., ed., 1979a, A study of global sand seas: U.S. Geological Survey Professional Paper 1052, 429 p.

$1979 \mathrm{~b}$, Introduction to a study of global sand seas, in McKee, E. D., ed., A study of global sand seas: U.S. Geological Survey Professional Paper 1052, Chapter A, p. 1-19.

McKee, E. D., and Bigarella, J. J., 1979a, Sedimentary structures in dunes, in McKee, E. D., ed., A study of global sand seas: U.S. Geological Survey Professional Paper 1052, Chapter E, p. 83-134.

1979b, Ancient sandstones considered to be eolian, in McKee, E. D., ed., A study of global sand seas: U.S. Geological Survey Professional Paper 1052, Chapter H, p. 187-236.

McKnight, E. T., 1940, Geology of the area between the Green and Colorado Rivers, Grand and San Juan Counties, Utah: U.S. Geological Survey Bulletin 908, 147 p.

Opdyke, N. D., and Runcorn, S. K., 1960, Wind direction in the Western United States in the late Paleozoic: Geologic Society of America Bulletin, v. 71, no. 7, p. 959-972.

Orgill, J. K., 1971, the Permian-Triassic unconformity and its relationship to the Moenkopi, Kaibab, and White Rim Formations in and near the San Rafael Swell, Utah: Brigham Young University Geologic Studies, v. 18, part 3, p. 131179.

Poole, F. G., 1962, Wind directions in late Paleozoic to middle Mesozoic time on the Colorado Plateau: U.S. Geological Survey Professional Paper 450-D, art. 163, p. 147-151.

Potter, P. E., 1967, Sandbodies and sedimentary environment, a review: American Association of Petroleum Geologists Bulletin, v. 51, no. 3, p. 337-365.

Rawson, R. R., and Turner-Peterson, C. E., 1979, Marine carbonate, sabkha, and eolian facies transitions within the Permian Toroweap Formation, northern Arizona, in Baars, D. L., ed., Permianland: Four Corners Geological Society Guidebook, Ninth Field Conference, p. 87-99.

Reiche, Parry, 1938, An analysis of cross-lamination-The Coconino Sandstone: Journal of Geology, v. 46, no. 7, p. 905-932.

Reineck, H. E., and Singh, I. B., 1975, Depositional sedimentary environments: Springer-Verlag, $439 \mathrm{p}$.

Ritzma, H. R., 1980, Migration and entrapment of petroleumexamples from Utah oil-impregnated sandstone deposits [abs.]: American Association of Petroleum Geologists Bulletin, v. 64 , no. 5 , p. 774 . 
Scholle, P. A., 1978, A color illustrated guide to carbonate rock constituents, textures, cements, and porosities: American Association of Petroleum Geologists, Memoir 27, $241 \mathrm{p}$.

Steele-Mallory, B. A., 1981a, The Permian White Rim Sandstone Member of Cutler Formation: An example of a coastal dune field [abs.]: American Association of Petroleum Geologists Bulletin, v. 63, no. 3, p. 570.

1981b, The depositional environment and petrology of the White Rim Sandstone Member of the Permian Cutler Formation, Canyonlands National Park, Utah: Colorado School of Mines, Masters Thesis, T-2436, $121 \mathrm{p}$.

1982, The depositional environment and petrology of the White Rim Sandstone Member of the Permian Cutler Formation, Canyonlands National Park, Utah: U.S. Geological Survey Open-File Report 82-204, 81 p.
Trumble, D. E., 1980, Cenozoic tectonic history of the Great Plain contrasted with that of the southern Rocky Mountains, a synthesis: The Mountain Geologist, v. 17, no. 3, p. 59-69.

Triplehorn, D. M., 1966, Glauconite provides good oil search data: World Oil, v. 162, no. 1, p. 94-97.

Walker, R. G., 1979, Eolian sands, in Walker, R. G., ed., Facies models: Geoscience Canada, Reprint Series 1, Geologic Association of Canada, p. 33-41.

Weaver, C. E., and Pollard, L. D., 1973, The chemistry of clay minerals: Developments in Sedimentology 15: Elsevier Scientific Publishing Co., p. 25-45.

Williams, P. L., 1964, Geology, structure and uranium deposits of the Moab Quadrangle, Colorado and Utah: U.S. Geological Survey Miscellaneous Investigations Series, Map I-360. 


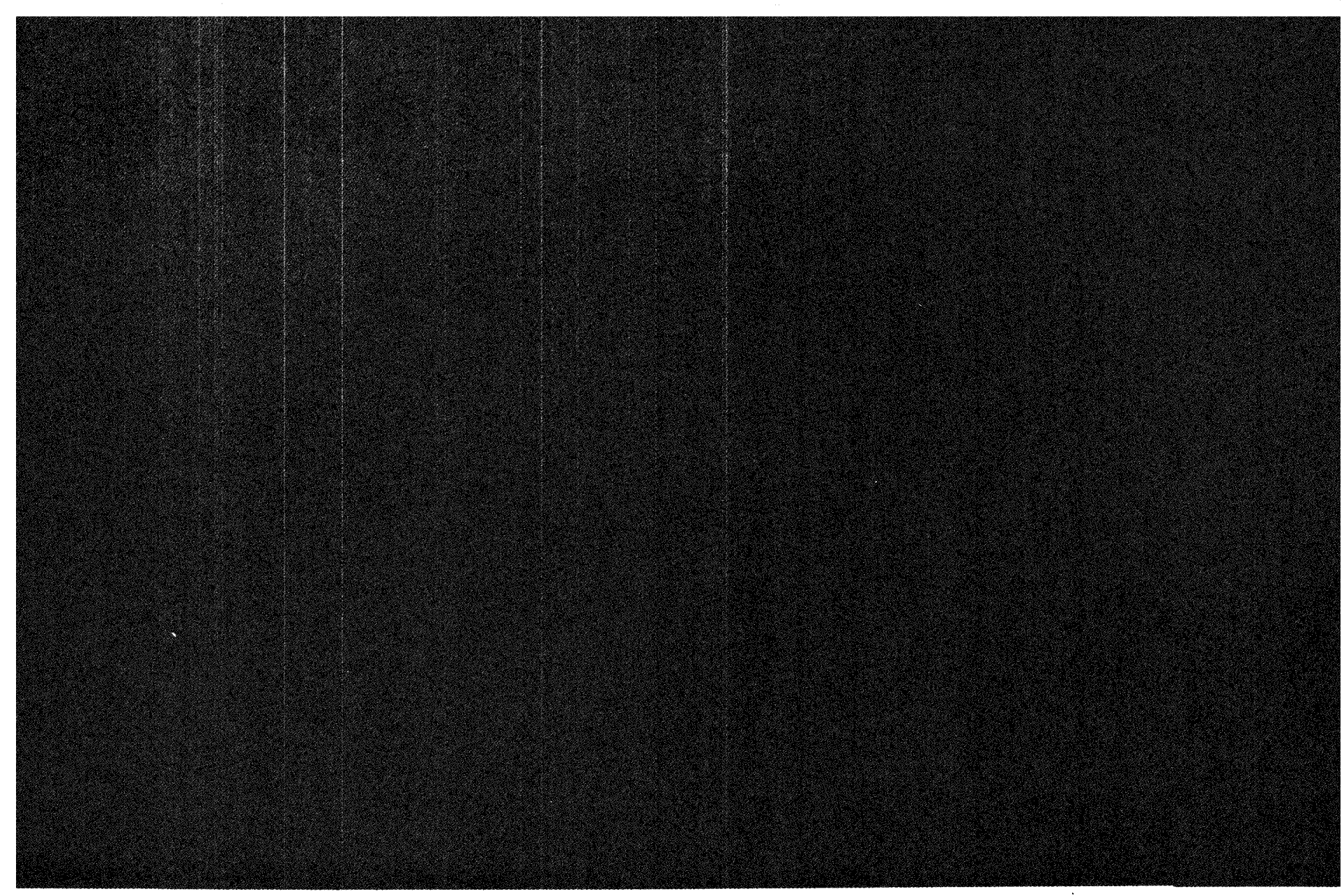

